\title{
NOBLES VALENCIANOS EN EL SERVICIO REGIO. LA PROVISIÓN DEL OFICIO DE PORTANTVEUS DE GOBERNADOR ULTRA SEXONAM EN LA EDAD MODERNA*
}

\author{
DAVID BERNABÉ GIL \\ Universidad de Alicante
}

En la época de los Austrias, eran varias las instituciones de que disponía la Monarquía para tratar de hacer efectiva la acción de gobierno sobre los distintos territorios que la integraban. Para la Corona de Aragón, el sistema de la Gobernación General, de origen medieval, aunque mantuvo a grandes rasgos su estructura durante todo el periodo -hasta su abolición por Felipe $\mathrm{V}$ - no pudo permanecer del todo ajeno a las consecuencias de un doble proceso, que, ciertamente, acabó alterando su específica incardinación en el organigrama administrativo. Por un lado, se asiste a un paulatino descabezamiento del sistema, al irse vaciando de contenido efectivo - hasta llegar a extinguirse- la figura del Gobernador General -tradicionalmente vinculada a la familia real-, que acabó trasladando hacia los Portantveus territoriales el protagonismo de que antaño aquélla había gozado; si bien con un alcance ahora seguramente más limitado. Por otro, el paulatino reforzamiento de las Lugartenencias Generales del monarca en cada reino, asumidas por los Virreyes, derivó en un desplazamiento en sentido descendente de todo el sistema de la Gobernación en la jerarquía de poder, al quedar aquéllos subordinados a éstos. Que esta dinámica institucional -magníficamente descrita por J. Lalinde ${ }^{1}$ - acarreara pérdidas de poder efectivo otrora en manos de los oficiales de la Gobernación es cuestión que, sin embargo, no debe darse automáticamente por sentada; al menos, mientras no se examinen las relaciones mantenidas con otros núcleos de poder, como eran -entre otros- los municipios y las jurisdicciones señoriales.

\footnotetext{
* Este trabajo ha sido realizado en el marco del Proyecto de Investigación HUM2007-63505, financiado por el Ministerio de Educación y Ciencia

1. Lalinde ABADÍA, Jesús: La Gobernación General en la Corona de Aragón, Madrid-Zaragoza, 1962.
} 
Como máxima autoridad en el territorio que tenía asignado, era función esencial del Gobernador el ejercicio de la alta jurisdicción en nombre del Rey. Ello comportaba, en primer lugar, impartir la justicia con equidad, sin dejarse intimidar por los poderosos, con imparcialidad, sin favoritismos a parientes o deudos, y con la necesaria perseverancia. En el terreno estrictamente judicial, el sistema de la Gobernación se configura esencialmente como un tribunal de segunda instancia para causas procedentes de los tribunales municipales -en temas matrimoniales, contractuales, pequeños delitos, etc- y, por consiguiente, como antesala de la Real Audiencia. Pero también se le reconocen amplias competencias en primera instancia, pudiendo asumir o intervenir directamente en multitud de asuntos relativos a prostitución y amancebamiento, nobles y caballeros, señoríos de jurisdicción alfonsina, municipios de realengo, entre otros.

Como supremos responsables del mantenimiento del orden público y de la paz social, compete a los Gobernadores la persecución de bandoleros, malhechores y delincuentes; han de garantizar el cumplimiento de las pragmáticas y órdenes reales, que pueden llegarle directamente del Consejo de Aragón o a través del Virrey; y defender los derechos y regalías de la Corona -en combinación con el Bayle General- frente a cualquier otra instancia de poder, como son los señores de vasallos, los municipios y la Iglesia. Corresponde al Gobernador el mando militar y la defensa de su distrito; y entre sus obligaciones figura, asimismo, la de recorrer el territorio, visitar los municipios de realengo y, en definitiva, hacer acto de presencia allí donde sea necesario para la salvaguarda de la jurisdicción real. Sus amplias competencias, en cuyo análisis no vamos a entrar aquí -pero que ya fueron objeto de atención para juristas como Arnau Joan, en el siglo XIV; Pedro Belluga, en el XV; Lorenzo Matheu y Sanz, en el XVII; y, más recientemente, Jesús Lalinde ${ }^{2}$ - no permanecieron, empero, fosilizadas; y, en algunas de las vertientes que conformaban la autoridad conferida, no estuvieron exentas de disputas, al convertirse fácilmente en ámbitos de confluencia competitivos con otras instancias concurrentes, entre las que destacaba la institución municipal.

Mencionados a grandes rasgos los asuntos fundamentales que competían a la Gobernación y dejando para otra ocasión un más atento seguimiento de la práctica del poder desarrollado por los integrantes de ese sistema institucional en Orihuela y de la naturaleza y significado de los roces que podían suscitar sus actuaciones, interesa detenerse en los criterios por los que se rigió la provisión de aquéllos, como elemento esencial para aspirar a una más completa caracterización. El papel de los oficiales de la Gobernación en su conjunto debió alcanzar, en efecto, la suficiente relevancia como para que en su reclutamiento se barajaran razones y argumentos no exentos de elevada significación política y social; e incluso cultural, en el sentido con que últimamente se viene considerando esta vertiente de las manifestaciones del poder, que se refleja especialmente en la utilización del lenguaje y de determinadas formas discursivas. De

2. Además de ibídem, que contiene las referencias oportunas a los juristas mencionados, una útil guía de las disposiciones forales sobre la jurisdicción del Gobernador, en TARAÇONA, Pere Hieroni: Institucions dels furs y privilegis del Regne de Valencia, Imp. por Pere de Guete, Valencia, 1580 (ed. facsímil, Librerias Paris-Valencia, Valencia), pp. 29-36. 
ahí la conveniencia de desentrañar los elementos intervinientes en la provisión de tales cargos, así como la de conocer los curricula de los que fueron «agraciados»y, en la medida de lo posible, también de los aspirantes frustrados a ejercerlos.

La indagación de las circunstancias que rodeaban los mecanismos de selección del personal que debía servir los diferentes oficios puede contribuir a un mejor conocimiento, no sólo de su contenido institucional, sino también de los vectores convergentes en el proceso de toma de decisiones al más alto nivel; al tiempo que nos informa del perfil humano, social y profesional exigible a -y esperado de- los candidatos, y de los discursos en que se encuadra su reclutamiento. En tanto que ejemplar manifestación de la administración de la gracia, como forma específica de la aplicación de los principios por los que se regía la justicia distributiva ${ }^{3}$, la elección de los oficiales regios representaba la culminación de un proceso selectivo en el que intervenían una serie compleja de factores cuya incidencia puede resultar reveladora de la configuración de las estructuras de poder.

Con estas perspectivas, el presente trabajo, que se centra especialmente-debido a condicionantes de naturaleza estrictamente heurística ${ }^{4}$ - en el siglo XVII, se limitará a una de las dos Gobernaciones en que se dividía el reino de Valencia, y al oficial que ocupaba la cúspide del sistema en el territorio correspondiente, cual era el Portantveus de General Governador; en nuestro caso concreto intitulado denllá Xixona o, simplemente, de Orihuela, por tener en esta ciudad su sede oficial. A veces, también es mencionado en la documentación coetánea como Gobernador de Alicante, porque las necesidades del oficio le llevaban a residir en esta ciudad varios meses al año; circunstancia que originó las correspondientes protestas, e incluso algunos procesos judiciales, por parte de la de Orihuela, que veía peligrar su capitalidad. Mas no se abordará aquí esta cuestión, como tampoco la referente a la provisión de los otros cargos que se mencionan a continuación, cuyo análisis reservamos para otra ocasión ${ }^{5}$.

3. HESPANHA Antonio Manuel: «La economía de la gracia», en La gracia del derecho. Economía de la cultura en la Edad Moderna, Centro de Estudios Constitucionales, Madrid, 1993; DE Dios, Salustiano: Gracia, merced y patronazgo real. La Cámara de Castilla entre 1474-1530, Madrid, 1993; CÁRCELES DE GEA, Beatriz: «La 'justicia distributiva' en el siglo XVII (Aproximación político-constituciona)», Chronica Nova, ${ }^{\circ} 14$, Granada, 1984-85, pp. 93-122.

4. La presente investigación se basa esencialmente en la documentación del Consejo de Aragón (Secretaría de Valencia) custodiada en el ACA, que arranca de la última década del siglo XVI. De ahí que, por el momento, solo haya sido posible alcanzar el necesario nivel de sistematización para el siglo XVII. Las escasas referencias a la centuria precedente, obtenidas a partir de otras fuentes, se harán con las debidas precauciones y, generalmente, como puntual elemento de comparación con los rasgos que aparecen en el periodo que es objeto de especial atención.

5. VILAR RAmíreZ, Juan Bautista: Orihuela, una ciudad valenciana en la España Moderna, Caja de Ahorros de Alicante y Murcia, Murcia, 1981, III, pp. 723-736; SALVAdOR Esteban, Emilia: «La Gobernación valenciana durante la Edad Moderna. Cuestiones en torno a su singular estructura territorial», Studia Historica et Philologica in honorem M. Batllori, Roma, 1984, III, pp. 443-455; AlBEROLA RoMÀ, Armando: «La organización político-administrativa durante la época moderna», en MESTRE SANCHÍs, Antonio (dir.): Historia de la provincia de Alicante. IV. Edad Moderna, Edic. Mediterráneo, Murcia, 1985, pp. 213-238; BERNABÉ GIL, David: «Alicante en la monarquía hispánica», en Historia de la ciudad de 
Con una demarcación territorial no demasiado extensa -unos $2.900 \mathrm{Km} 2-$, pero densamente poblada -en torno a los 45.000 habitantes a principios del siglo XVII-, la Gobernación de Orihuela contaba asimismo con un Lugarteniente del Portantveus en la misma capital, cuya jurisdicción se extendía por el mismo territorio, y con un Subrogado del Portantveus, con sede en Alicante, que la ejercía en nombre del primero en el término general de esta ciudad portuaria. Dos asesores juristas, con sedes respectivas en Orihuela y en Alicante, aportaban el elemento técnico y completaban la oficialía. La ya mencionada pequeñez territorial de la Gobernación sureña, en comparación con la otra existente en el Reino de Valencia -con sede en la misma capital-, apenas se dejaba traslucir, sin embargo, en la relevancia otorgada a su titular, cuyo rango le situaba inmediatamente por debajo del Virrey y casi a la par con el otro Portantveus, del que, en cualquier caso, se consideraba totalmente independiente. Mas allá de su exacta ubicación en la jerarquía de mando, la lejanía respecto de la sede virreinal y su condición fronteriza, respecto de Castilla, dotaban al oficio en cuestión de unas connotaciones especiales, en lo referente a las capacidades exigidas para imponer la autoridad, que le hacían poco idóneo para jóvenes inexpertos o de espíritus flojos, condescendientes, pusilánimes o indecisos; sobre todo, en circunstancias -tan frecuentesde bandosidades y alteraciones de la paz social.

Para los oficiales regios, una de las principales cualidades a valorar era la capacidad para mantener el orden público. Así, con motivo de la vacante producida en la titularidad el oficio en 1656, el Virrey se dirigía al Consejo de Aragón para que no demorase la elección del sucesor, señalando «la importancia de esta provisión con nuevos motivos que obligan a no diferirlo, cuando se experimenta multiplicidad de delitos y desórdenes en Alicante y Orihuela, siendo así que entre otros a un mismo tiempo me refieren cinco arcabuçaços en diferentes partes de aquella Gobernación y los tres de ellos con homicidios, en que está empeçada a incluir parte de la nobleça, y puede estarlo toda con gran inconveniente del sosiego publico» ${ }^{6}$. Este estado de inquietud, aunque posiblemente agravado por la interinidad de la máxima autoridad territorial, sobrepasaba lo meramente coyuntural o excepcional.

Al cabo de unos meses, la situación que encontró el recién nombrado asesor jurídico de la Gobernación no era muy diferente, pues según relató después, al dejar el cargo por jubilación, «quando vine a ella la hallé tan inquieta que en dando las primeras oraciones no había quien se atreviese a abrir las puertas de su casa y ya con tales principios de unos desdichados bandos ${ }^{7}$. Mas los esfuerzos realizados por los oficiales regios para restaurar la paz social no debieron dar los frutos esperados, pues en 1663 era el Virrey quien, nuevamente urgiendo la provisión del cargo de Gobernador, señala-

Alicante. Edad Moderna, Comisión V Centenario de la ciudad de Alicante, Alicante, 1990, vol. III, pp. 151-160; y, del mismo, «Oficiales de la Gobernación General y oligarquía municipal en Orihuela durante el siglo XVII», en Fernández Albaladejo, Pablo (ed.): Monarquía, Imperio y Pueblos en la España Moderna, C.A.M.-Universidad de Alicante, A.E.H.M., Alicante, 1997, pp. 569-582.

6. ACA: CA, leg. 740, exp. 31/2, informe del Virrey, de 28 de diciembre de 1657.

7. ACA: CA, leg. 750, exp. 2/3, memorial del Dr. Hilario Palmir, de 14 de septiembre de 1660. 
ba al Vicecanciller del Consejo de Aragón las cualidades que debían adornar al elegido y las razones para ello: "la necesidad grande de que este oficio convendría se diese a persona con autoridad y brío por lo que el estado de las cosas de Orihuela lo pedía respecto de lo poco que obra la justicia y convenía adelantar la buena administración de ella» ${ }^{8}$. En 1676, en fin, un juez de la Audiencia ensalzaba la labor llevada a cabo por el último titular del oficio, teniendo en cuenta «que por ser raya del Reyno es el abrigo de los delinquentes y todo genero de gente, asi facinerosos como ladroncillos....y por adolecer aquella tierra mas que otras del vicio de los amancebamientos» ${ }^{9}$

Por parte de los dos grandes municipios donde el Gobernador desempeñaba sus funciones se valoraba especialmente su capacidad para hacer valer la jurisdicción real y sus dotes de mando en el terreno militar. En 1645, las ciudades de Orihuela y de Alicante no ocultaron su firme desacuerdo con el reciente nombramiento efectuado en favor de D. Gerardo Ferrer. Mención aparte de las razones profundas que le llevaron a expresar su disconformidad, el consistorio oriolano solicitaba para hacerse cargo de la Gobernación «persona en quien concurran todas las partes de un buen ministro, por distar aquella ciudad de la de Valencia treinta leguas, y en una necessidad prompta no tener de quien tomar consejo, y haver en ella dos ciudades y muchas villas, con un marquesado, quatro condados, con tres baronias, y quinze leguas de mar que guardar, donde muy ordinariamente suelen acudir los moros y enemigos de la santa fe». Y no muy distinta era la posición alicantina al respecto, pues también se indicaba «que siendo dicha ciudad y gran parte de la governacion frontera del enemigo y ocurrir de ordinario en su puerto las Reales armadas de V. Magd. requiere persona de mucha edad, capacidad, y experiencia en las armas $\rangle^{10}$.

Encontrar la persona adecuada para regir el oficio con rectitud y eficacia no era tarea fácil, y el grado de acierto dependía de la combinación de una variada serie de elementos que intervenían en la elección. Al igual que ocurría con otros altos cargos de la administración territorial, la provisión de éste correspondía a Su Magestad, que solía asesorarse para ello con el Consejo de Aragón. El grado de participación de esta importante pieza del sistema polisinodial en la administración de la justicia distributiva no siempre se materializaba, sin embargo, del mismo modo; y en el caso concreto que nos ocupa -la elección del Portanveus de Orihuela- es posible distinguir tres etapas diferenciadas.

En la primera de ellas, que alcanzaría hasta bien entrado el siglo XVII, los nombramientos de Portantveus se habrían realizado sin duración temporal prefijada, a beneplácito real, que equivalía prácticamente hasta su jubilación por edad, impedimento físico para ejercer, renuncia, o bien hasta nueva promoción a otra plaza de mayor rango. En esta modalidad de nombramientos con carácter temporalmente indefinido

8. ACA: CA, leg. 759, exp. 7/2, el Virrey al Vicecanciller del Consejo de Aragón, en 28 de agosto de 1663.

9. AHN: Consejos, leg. 18.465, Informe de D. Jaime Madroño sobre las acusaciones contra D. Miguel Fenollet, en Valencia, a 21 de abril de 1676.

10. ACA: CA, leg. 889, exp. 151/1-6, memoriales de las ciudades de Alicante y de Orihuela, anteriores al 17 de octubre de 1645 . 
habría que incluir seguramente todos los efectuados a lo largo del siglo XVI. Así, D. Pedro Maça de Lizana y Carroz permaneció en el cargo desde que fuera nombrado en 1521, en plena revuelta agermanada, hasta su fallecimiento, ocurrido 25 años más $\operatorname{tarde}^{11}$. En cambio, su sucesor, D. Ximén Pérez Pertusa, estuvo poco tiempo en el mismo $^{12}$, pues en 1548 dio comienzo el mandato de D. Guillem de Rocafull, que ejerció hasta finales de 1552, cuando fue relevado del oficio para ocuparse del gobierno militar de la plaza de Menorca $^{13}$. Más amplio fue el periodo correspondiente a D. Juan de Moncayo, pues se extendió entre 1553 y $1566^{14}$; y el de D. Enrique de Palafox, que ejerció entre 1566 y $1581^{15}$. Siguieron a éste otros dos breves mandatos, cuales fueron los de D. Juan Quintana, entre 1581 y $1586^{16}$, y de D. Ximén Pérez de Calatayud, que ocupó la plaza solo dos años, hasta $1588^{17}$. D. Alvaro Vique y Manrique, sin embargo, sirvió en la misma durante 19 años, hasta que en 1607 se le admitió la renuncia para poder atender los pleitos y la administración del mayorazgo que acababa de heredar tras la defunción de su hermano D. Pedro ${ }^{18}$. Con D. Juan Ferrer y Calatayud, que le sucedió en el oficio por otros 19 años, hasta su fallecimiento, en 1626, se produce la transición a un nuevo régimen.

Carácter interino tuvo en la práctica, durante esta etapa, únicamente D. Nuño del Aguila. Su designación se produjo a finales de 1552, para cubrir la vacante dejada por Rocafull, pero en el privilegio de nombramiento se preveía una duración más amplia, pues se especificaba «ad tempus trium annorum tantum modo a die datis presentis inde

11. De 1521 son las primeras referencias que conozco en que figura ya como Gobernador de Orihuela. Cfr. Escolano, Gaspar: Década Primera de la Historia de la Ciudad y Reino de Valencia, Valencia, 1611 (ed. facsímil de Librerias Paris-Valencia, Valencia) p. 692 y ss., donde se relatan sus múltiples actuaciones en defensa del bando realista durante la revuelta; y CARRASCO RODRIGUEZ, Antonio: la ciudad de Orihuela y el pleito del Obispado en la Edad Moderna, Tesis doctoral, Universidad de Alicante, 2001, p. 52 (existe publicación digital). En 1546 aun continuaba ejerciendo el oficio, hasta que el 21 de octubre de ese año su hermano D. Juan menciona en carta a la ciudad de Orihuela su reciente fallecimiento. AMO: Contestador de 1546, ff. 13, 244.

12. Refiere su presencia en 1547, BELLOT, Pedro: Anales de Orihuela (ss. XIV-XVI), ed. de TORRES FonTES, Juan, Murcia, 1954, t. II, p. 88; si bien la lista que ofrece no es del todo fiable. No obstante, hay clara constancia de que ejercía en dicho año, en AMO: Lib. $N^{o} 2.031$, f. 528v.

13. ESCOLANO, Gaspar: Op. cit. pp. 533-534, donde se afirma que accedió a la plaza de Orihuela en 1548 y se detallan algunas actuaciones militares protagonizadas posteriormente en Menorca y en Mallorca, de la que llegó ser nombrado Virrey. Las referencias a su cese en Orihuela y nuevo destino en Menorca, en AMO: Contestador de 1553, ff. 212.213v, 215-215v.

14. AMO: Contestador de 1553, ff. 215-215v, privilegio de nombramiento, de 3 de mayo de 1553. En 1565 Moncayo todavía seguía al frente de la Gobernación, pero no así en 1567, en que figura ya su sucesor, D. Enrique de Palafox. AMO: Contestador de 1565, ff. 79-81, 621; Contestador de 1567, ff. 118, 119. Mi desconocimiento de referencias documentales correspondientes a 1566 impide precisar más.

15. Para la primera fecha, vid. nota anterior; para la segunda, AMO: Contestador de 1582, f. 328.

16. Para la primera fecha, vid. nota anterior; para la segunda, AMO: Contestador de 1586, f. 285.

17. Para ambas fechas, vid. notas 16 y 18 , respectivamente.

18. ACA: CA, leg. 651, exp. 32, consulta del Consejo de Aragón, de 17 de diciembre de 1588; leg. 866, exp. 28/3, terna del Virrey, de 26 de noviembre de 1607. 
computandoris et interim ad meram et liberam voluntatem ${ }^{19}$. En cualquier caso, el mandato de D. Nuño apenas tuvo ocasión de hacerse efectivo, pues al ser de nacionalidad castellana -natural de Avila- las autoridades municipales recurrieron de inmediato la orden regia por considerar que atentaba contra las disposiciones forales; $y$, al poco tiempo - para atajar el conflicto que se avecinaba-, se designó en su lugar al aragonés D. Juan de Moncayo ${ }^{20}$.

A D. Juan Ferrer y Calatayud, designado en 1607, habría de sucederle, en 1626, su hijo primogénito, D. Luis, quien, tras otros 19 años en el cargo, renunció al mismo en beneficio de su hijo, D. Gerardo, en $1645^{21}$. Tras estos mandatos de larga duración, D. Gerardo solo pudo ejercer hasta su prematuro fallecimiento, en 1656, poniendo con ello punto y final a una segunda etapa caracterizada por la sucesión hereditaria en la titularidad de la Gobernación ${ }^{22}$. Tratábanse por tanto, los Ferrer de una saga familiar que, durante medio siglo y a lo largo de tres generaciones, acaparó el oficio, a pesar de las continuas peticiones de la ciudad de Orihuela para que se limitara la duración del mismo a un solo trienio.

En realidad, el origen de estas reclamaciones del consistorio oriolano se remontaba a tiempo atrás, pues ya figuran en las solicitudes expresadas en las cortes de 1565; $\mathrm{y}$, desde entonces, se repitieron en todas las sucesivas reuniones de cortes $-1585,1604$, 1626- y en otras oportunidades que hubo para plantear el tema directamente ante el Consejo de Aragón, como en 1640. Sin llegar a exponerlo de forma explícita ante el Monarca - pero sí en el seno del consistorio-, consideraba la ciudad que, de atenderse su petición, fijando en un trienio la duración del cargo, se rebajaría el nivel de prepotencia con que -según su criterio- obraban los Gobernadores perpetuos en el ejercicio del oficio. Más que un excesivo celo en el desempeño de sus funciones, temían los abusos de poder que, especialmente en determinadas coyunturas, habían acarreado no pocos pleitos, encuentros y desavenencias con las autoridades municipales. Es por ello que, además de tratar de acortar su mandato, se persiguiera también con insistencia su obligatorio sometimiento a residencia, una vez concluido aquél, como fórmula adecuada para responder de posibles atropellos ${ }^{23}$.

19. AMO: Contestador de 1553, ff. 212-213v, privilegio de nombramiento, de 26 de diciembre de 1552.

20. Ibidem, ff. 158-158v, 203-205, 211v, 224-225, cartas de la ciudad de Orihuela a sus síndicos y abogados en Valencia, y en la corte, y al Príncipe Felipe, entre el 21 de marzo y el 5 de mayo de 1553. D. Nuño trató de tomar posesión el 29 de abril, en la iglesia catedral oriolana, ante las autoridades municipales, que interpusieron dissentiment. El 3 de mayo fue despachado el nuevo privilegio a favor de Moncayo, pero aun transcurrieron algunos días hasta que el nuevo nombramiento fue conocido en la ciudad.

21. ACA: CA, leg. 889, exp. 151/3-6, memoriales de las ciudades de Alicante y Orihuela, anteriores a 17 de octubre de 1645 .

22. ACA: CA, leg. 736, exp. 17/1-19, documentos varios sobre la provisión de la plaza de Gobernador de Orihuela, desde febrero hasta septiembre de 1656.

23. He tratado de estas cuestiones más extensamente, en «Oficiales de la Gobernación...», art. cit. donde podrán encontrarse las referencias oportunas. 
El sentido -inútilmente oculto- de las aspiraciones de la ciudad no podía pasar desapercibido para la Corona, cuyos intereses se cifraban esencialmente en reforzar la autoridad del oficio. Su duración a real beneplácito podía contribuir a ello, tal como aseguraba un Virrey en 1640, al advertir que «ser trienal el Governador sería quitar la authoridad a officio tan preeminente, y en ninguna parte convenga que la tenga mas que en Orihuela» ${ }^{24}$; mas no necesariamente el carácter hereditario que había llegado a alcanzar. Cuando en 1613 D. Juan Ferrer solicitó a Felipe III -en remuneración a los múltiples servicios ofrecidos, cuya relación incluía- «haga merced de dalle por adjunto en el dicho cargo de Governador de Orihuela con futura succession a Don Luys Ferrer, su hijo, que es el mayor de los cuatro que tiene», la consulta del Consejo de Aragón fue inequívocamente favorable; y no solamente «por su edad y qualidad y por la buena relacion que ay de las partes y esperanças de Don Luis Ferrer su hijo», sino sobre todo en atención a que «esto redundara en mayor servicio de Su Magestad y mejor administracion de la justicia». Con estos argumentos, la decisión final difícilmente podía resultar denegatoria. Pero el Monarca se cuidó de señalar su carácter excepcional, sin ahorrar una ligera advertencia para que no cundiera el ejemplo: «el consejo escuse quanto pudiere de consultarme estas futuras sucesiones por los inconvenientes que traen consigo» ${ }^{25}$. Dos décadas más tarde, sin embargo, D. Luis volvió a pedir exactamente lo mismo para su hijo D. Gerardo: «merced de la conjunción de dicho oficio.... para que desa manera, entrambos, puedan acudir a el», sin que haya constancia de que ahora se otorgara la gracia solicitada ${ }^{26}$.

Es posible que las tensiones producidas con algunos Portantveus aconsejaran ceder ante las reiteradas pretensiones oriolanas de reducir a un trienio la duración del oficio; de modo que en cortes de 1645 el Monarca accedió finalmente a la solicitud planteada, incluyendo asimismo al cargo de Lugarteniente del Portantveus de Valencia en Castellón de la Plana. Habrá que esperar hasta 1656, no obstante, para la puesta en ejecución de la disposición de cortes, a fin de no lesionar los derechos del ocupante. Al producirse entonces la vacante por defunción de D. Gerardo, los Ferrer aun intentaron -y consiguieron- colocar un nuevo miembro familiar. A tal efecto, el anciano padre del difunto y antiguo Gobernador, D. Luis Ferrer y Proxita, propuso a otro hijo suyo, D. Gaspar ${ }^{27}$; mientras que una prima hermana del fallecido, $\mathrm{D}^{\mathrm{a}}$ Ana, solicitaba la plaza para su hermano D. Luis ${ }^{28}$; quién, contra todo pronóstico, se hizo finalmente con el cargo.

24. ACA: CA, leg. 718, exp. 72/12, informe del Virrey y de la Real Audiencia sobre un memorial de 18 peticiones de Orihuela, de 5 de junio de 1640.

25. ACA: CA, leg. 633, exp. 2/5, consulta del Consejo de Aragón, de 27 de junio de 1613, y respuesta de Su Magestad.

26. ACA: CA, leg. 876, exp. 62; memorial de D. Luis Ferrer de Proxita, visto en el Consejo de Aragón el 21 de abril de 1632.

27. AMO: Contestador de 1656, ff. 254-254v, carta de D. Luis Ferrer a los jurados de Orihuela, en Alicante, a 17 de enero de 1656.

28. Ibídem, f. 255, carta de $\mathrm{D}^{\mathrm{a}}$ Ana Ferrer a los jurados de Orihuela, en Alicante, a 17 de enero de 1656. 
La designación de D. Luis Ferrer Aragón de Apiano para ocupar, por un trienio, la Gobernación de Orihuela en 1656 debió sorprender a todos los sectores implicados, de un modo u otro, en el proceso de selección: En primer lugar, al Virrey y al Consejo de Aragón, pues en ninguna de las ternas presentadas por uno y otro había figurado como candidato; pero quizás también al consistorio oriolano, que, secundando los deseos del anciano ex-Gobernador, había recomendado a D. Gaspar. La sorprendente apuesta de los jurados de 1656 por este nuevo descendiente directo del mismo linaje que venía monopolizando el oficio durante media centuria, cuando afirmaban que «tenemos muy en la memoria lo bien que governo en esta ciudad el abuelo, padre y hermano de D. Gaspar Ferrer y Proxita ${ }^{29}$, encaja mal con el informe que habían remitido sus antecesores, once años atrás, con motivo de la sucesión de los Ferrer en el oficio. Tras recordar entonces las tropelías cometidas por los dos primeros miembros de la saga, que incluso les llevaron a ser «residenciados» por orden real -y, en el caso de D. Luis, suspendido en el ejercicio del cargo por seis años, luego rebajados a sólo dos- el consistorio había augurado en 1645 «que el dicho D. Gerardo Ferrer ha de tener la misma enemiga a los vezinos de aquella ciudad por razon de dichas residencias de padre y aguelo y el hazerle merced del Govierno ha de ser ponerles en manos de su mayor enemigo» ${ }^{30}$.

Si la recomendación de D. Gaspar en 1656 reflejaba las divisiones internas en el seno de la oligarquía municipal, la elección de D. Luis era un claro ejemplo de la discrecionalidad del monarca en la administración de la gracia, al tiempo que expresaba la eventual operatividad de los cauces no institucionalizados para obtenerla. Con todo, no dejó de representar una excepción respecto de lo que fue el procedimiento habitual en la provisión del oficio durante la tercera etapa que ahora se iniciaba.

La selección del oficio de Portantveus, como la de otros altos cargos de la administración real, solía realizarse tradicionalmente por el Monarca a partir de una terna jerarquizada que era preparada por el Consejo de Aragón. Aunque por el momento resulta difícil fijar el origen de esta práctica, fue norma durante el siglo XVII que el Sacro y Supremo Consejo, a su vez, solicitara previamente al Virrey una lista -asimismo ordenada- de candidatos idóneos, a partir de la cual poder valorar. La mayor proximidad física del Lugarteniente regio a las bases de reclutamiento de un oficio que solía recaer en naturales del reino de Valencia justificaba este tipo de consultas. Y también las ciudades de Orihuela y de Alicante solían emitir a veces su opinión, independientemente de que fueran consultadas al respecto. El primer listado de posibles candidatos al ejercicio del cargo de Portantveus procedía, por tanto, del reino de Valencia; y era a partir de esta relación nominal como el Consejo daba forma a la consulta definitiva que debía elevar al Monarca.

La comunicación con Valencia no agotaba, sin embargo, las fuentes de información con que contaba la corte acerca de la idoneidad de los potenciales candidatos.

29. ACA: CA, leg. 736, exp. 17/13, carta de los jurados de Orihuela al Consejo de Aragón, de 22 de enero de 1656.

30. ACA: CA, leg. 889, exp. 151/6, memorial de la ciudad de Orihuela, de 1645. 
Además de las ternas virreinales - cuyo proceso de formación es asunto no carente de interés, aunque un tanto esquivo en sus posibilidades de investigación-, también llegaban a la corte memoriales elevados por particulares que expresaban su deseo de ser tenidos en cuenta a la hora de decidir la provisión del oficio. Estos memoriales, donde los pretendientes exponían los méritos contraídos, con especial insistencia en los servicios realizados a la Corona, podían introducirse directamente en el Consejo o llegar previamente a Valencia, al objeto de granjearse el apoyo del Virrey y, de este modo, conseguir su inclusión en la terna que había de enviarse a Madrid. En tales casos, solían formar parte de la documentación tramitada por el Virrey, sin perjuicio de su remisión directa a la corte por parte de los interesados ${ }^{31}$.

La presentación de la candidatura correspondiente también podía comunicarse de forma oral, en conversaciones privadas con el Virrey o con algunos magistrados de la Audiencia, o a través de persona interpuesta, pues no era preceptivo que quedara reflejada por escrito. De hecho, de un total de 45 individuos cuyos nombres llegaron a barajarse en las 16 ocasiones en que hubo de proveerse el oficio mediante este sistema a lo largo del siglo XVII, sólo he podido localizar memoriales autógrafos con exposiciones curriculares propias para 21 pretendientes. De los 24 candidatos restantes, algunos también debieron elevar sus memoriales respectivos -que se han perdido o no he conseguido encontrar-; pero otros, quizás sin molestarse en redactarlos, simplemente se las ingeniaron para hacer llegar sus pretensiones al conocimiento del Virrey y de su entorno. También los hubo, finalmente, que, sin deseos de aspirar al oficio, fueron incluidos en las ternas, con no poco desconsuelo por el temor a resultar elegidos; e incluso quienes no ocultaron su expreso rechazo a tal posibilidad y así lo hicieron saber. En consulta de 20 de junio de 1664, «el Consejo deja de proponer a D. Pedro Boil de Arenos, que fue en $2^{\circ}$ lugar en la consulta pasada, por haberse entendido que se excusaría de este gobierno y no ser justo dejar la aceptación del segunda vez a esta contingencia $\rangle^{32}$.

En la confección de las ternas por el Consejo de Aragón se tomaba en consideración, por tanto, la ordenación previa de candidatos establecida por el Virrey, pero también las informaciones que por diversos cauces llegaban a la corte acerca de los méritos de otros pretendientes. Con esta información, los miembros del Consejo -el vicecanciller, los regentes y los consejeros de capa y espada- elaboraban una terna, con orden de prelación establecido mediante votación nominal, en la que debían abstenerse los posibles deudos y parientes -hasta el tercer grado- de los pretendientes que concurrían. Llegado el caso de impedimento para votar a alguno de los candidatos, por razón de parentesco, el consejero afectado se ausentaba de la sala; pero antes debía establecer

31. ACA: CA, leg. 736, exp. 17/1-18. En carta fechada en Valencia el 1 de febrero de 1656 el Virrey remitía al Consejo la terna solicitada, señalando que «de los dos primeros remito a V.M. inclusos los memoriales que me dieron».

32. ACA: CA, leg. 759, exp. 7/7, consulta del Consejo de Aragón, de 5 de julio de 1664. Pese a ello, en su voto particular uno de los regentes insistía en incluirlo, al considerar que iría en beneficio de su honra (exp. 7/11, consulta del Consejo, de 15 de julio de 1664). 
su propia terna, que era tenida en cuenta para el cómputo global. La terna resultante del consenso mayoritario de los consejeros solía ser definitiva, a no ser que, antes de que el Monarca procediera al nombramiento del elegido, llegaran a la corte nuevas informaciones de relieve que hicieran aconsejable rectificar y presentar una lista distinta. La confluencia de todos estos elementos determinó que, a veces, fueran varias las ternas que se barajaron; e incluso las que llegaron a «subir» en consulta al Soberano. Así, para cubrir la vacante dejada en 1657 por D. Luis Ferrer de Aragón y Apiano, llegaron a confeccionarse cinco ternas distintas, además de la del Virrey; y en 1664, para encontrar sucesor a D. Diego Sanz de la Llosa, fueron siete las listas manejadas, pues tres miembros del Consejo tenían parientes entre los candidatos, algunos rectificaron sus primeras propuestas, y cuando finalmente se hizo elección, el designado renunció y hubo que reiniciar el proceso de consultas. Además de este tipo de renuncias, las discrepancias de los consejeros acerca de la idoneidad de los diversos candidatos junto a la incidencia del patronazgo y de las relaciones clientelares y familiares contribuyeron a mantener a veces bloqueada la provisión del oficio durante varios meses. Así ocurrió en 1656, pues desde la confección de la primera terna virreinal -el uno de febrerohasta que se formalizó la consulta definitiva del Consejo -el 28 de septiembre- transcurrieron ocho meses ${ }^{33}$.

Tras las sucesivas rectificaciones, que afectaban no sólo al orden de los candidatos, sino a su propia identidad, no siempre resultaba elegido el noble que encabezaba la lista procedente de Valencia. De hecho, solo en la mitad de los casos conocidos -cinco sobre diez, sin contar las reelecciones- se respetó íntegramente el criterio del Virrey, al hacer suya el Consejo -o la mayor parte de sus miembros- la primera posición de la terna remitida desde la capital del reino levantino: Se trató de las candidaturas de D. Juan Ferrer y Calatayud, en 160734; Juan Cascant y García de Lasa, en 1656 35 ; D. Pedro Boil de Arenós, en 1675 36 ; seguramente D. Josep de Borja Llansol, en $1692^{37}$; y D. Vicente Falcó y Blanes, en $1700^{38}$. Tan elevada frecuencia en la modificación de las propuestas virreinales por parte del Consejo ${ }^{39}$ difícilmente podía suscitar el aplauso de sus emisores, que, en algunas ocasiones, no ocultaron su malestar, al entender que

33. ACA: CA, leg. 736, exp. 17/1-19, terna del Virrey, y consulta del Consejo de Aragón, de las fechas referidas.

34. ACA: CA, leg. 866, exp. 28/3, terna del Virrey, de 26 de octubre de 1607.

35. ACA: CA, leg. 736, exp. 17/1, consulta del Consejo de Aragón, de 29 de julio de 1656. Pero esta consulta no llegaría a ser la definitiva, pues al poco tiempo el propio Virrey rectificó e indujo a ello también al Consejo.

36. ACA: CA, leg. 787, exp. 99, terna del Virrey, de 27 de agosto de 1675 y consulta del Consejo de Aragón, de 4 de septiembre del mismo año.

37. Así se deduce de ACA: CA, leg. 857, exp. 70/1, borrador de consulta del Consejo de Aragón, de agosto de 1700 .

38. Ibídem, exp. 70/4-5, terna del Virrey, de 10 de agosto de 1700 y consulta del Consejo de Aragón, de 18 del mismo mes y año.

39. Las ternas virreinales fueron modificadas, en lo que se refiere a la primera posición, al menos en 1657, $1664,1671,1673$ y 1678. 
ese desprecio iba en detrimento de su autoridad. En 1657 así lo hizo saber el Duque de Montalto cuando, tras desmentir las objeciones puestas en contra de su candidato, manifestaba «la conveniencia del servicio de V. Md. que los súbditos vean con approvacion las ternas y el concepto del Virrey, porque a los que servimos en estos puestos no nos respectan mas de quanto nos ven favorecidos y aprovados $\rangle^{40}$.

A diferencia del -relativamente escaso- grado de correlación existente entre las ternas virreinales y las del Consejo, las propuestas definitivas elevadas al monarca por este órgano sinodial sí solían resultar eficaces, pues solamente en dos ocasiones se designó a un pretendiente cuyo nombre no había llegado siquiera a figurar en ninguna terna -D. Luis Ferrer Aragón de Apiano, en $1656^{41}$; y D. Francisco Guerau Y Ciurana, en $1679^{42}$, mientras que, en otra ocasión, se alteró el orden, al designar la reina $\mathrm{D}^{\mathrm{a}}$ Mariana al segundo de la lista -el Marqués de la Casta, en $1664^{43}$.

Mas no siempre fue dura la pugna por hacerse un hueco en las ternas en una posición privilegiada. Ante las expectativas abiertas cuando se producía o se aproximaba una vacante, interesaba difundir cuanto antes la noticia para propiciar una abundante concurrencia de aspirantes, pues a mayor competencia más oportunidades habría de hallar la persona idónea. Y es que la preocupación por no suscitar la necesaria apetencia hacia el cargo entre los sectores de la nobleza mejor preparados no estaba del todo injustificada. Por un lado, algunos potenciales candidatos estimaban que su corta remuneración económica difícilmente compensaba la dedicación y las condiciones en que tenían que desarrollar su labor. Por otro, la corta duración del mandato tampoco actuaba precisamente como factor de atracción. Naturalmente, el problema no era hallar el mínimo de candidatos requerido para elaborar una terna -siempre habría alguien dispuesto a ofrecerse-, sino la calidad de los potenciales aspirantes. Tras varias décadas en que la sucesión hereditaria excluyó la formación de ternas, cuando en 1656 se retomó el procedimiento tradicional el Virrey de turno no ocultó su escepticismo respecto a la posibilidad de encontrar un candidato idóneo, pues «ha avido pocos concurrentes, porque no le hace tan apetecible la disposicion de Cortes que le constituie triennal» ${ }^{44}$.

La apreciación del Virrey habría de resultar, no obstante, manifiestamente errónea, pues fueron once, al menos, los candidatos que se barajaron en Madrid para la ocasión. Y al año siguiente, al vacar nuevamente el oficio por inmediata promoción del elegido, aun se añadirían otros tres aspirantes más. Tan elevado número de concurrentes no era fácil que volviera a alcanzarse ya en lo sucesivo, pues aunque en 1664 hay constancia de la presencia de una docena de candidatos, fue más habitual que

40. ACA: CA, leg. 740, exp. 31/1, terna del Virrey, de 28 de octubre de 1657.

41. ACA: CA, leg. 736, exp. 17/1, consulta del Consejo de Aragón, de 29 de julio de 1656.

42. ACA; CA, leg. 798, exp. 66/2, consulta del Consejo de Aragón, de 5 de diciembre de 1678.

43. ACA: CA, leg. 759, exp. 7/11, consulta del Consejo de Aragón, de 15 de julio de 1664.

44. ACA: CA, leg. 736, exp. 17/1, terna del Virrey, de 1 de febrero de 1656. 
no llegaran a la mitad, por término medio, en las restantes ocasiones ${ }^{45}$. La atracción que el oficio suscitaba en determinados sectores intermedios de la nobleza valenciana hizo que algunos de los aspirantes frustrados reincidieran en su actitud, expresando nuevamente su voluntad de concurrir en trienios sucesivos. O bien, la valía personal les hizo repetidamente acreedores a la plaza, a juicio de los virreyes y del Consejo. Al menos 15 individuos - del total de 62 que constituyen nuestro universo- fueron aspirantes a la Gobernación oriolana en dos ocasiones; y otros cuatro pretendientes lo hicieron en tres momentos distintos; con el previsible resultado de que algunos de ellos -cinco, del total de 19 reincidentes- obtuvieron premio a su perseverancia mediante la obtención del cargo: D. Diego Sanz de la LLosa, D. Pedro Boil de Arenós, D. Jaime Antonio Borrás, D. Josep de Borja Llansol y D. Vicente Falcó y Blanes. Otro más, D. Felipe Boil, fue elegido tras haber figurado ya en las ternas en dos ocasiones anteriores; aunque no parece que tal honor le hiciera finalmente gran ilusión, pues renunció de inmediato $^{46}$. Por consiguiente, la reincidencia en cualquiera de las ternas, en años distintos, añadía nuevas posibilidades de resultar elegido; pero sólo si venía avalada por una serie de cualidades personales que hicieran al candidato especialmente apropiado para el cargo. Haber concurrido ya en el pasado no era mérito que soliera esgrimirse en ocasiones posteriores; $\mathrm{y}$, de hecho, la mitad de los nombramientos recayeron sobre candidatos que figuraron entonces por vez primera en las propuestas. Pero tampoco restaba posibilidades.

Conseguir introducirse en una terna era una aspiración que, lógicamente, no todos los pretendientes podían ver cumplida; lo cual generaba una ligera frustración que debió afectar seguramente a algunos más de los nueve aspirantes que he podido detectar, entre quienes se ofrecieron de manera expresa a través de menorial ${ }^{47}$. La administración real, no obstante, disponía en el reino de Valencia de otros empleos a los que aspirar; de modo que algunos de los que no llegaron a obtener la plaza de Orihuela pudieron conformarse con las Lugartenencias de Játiva, Castellón, la propia

45. El carácter probablemente incompleto de los nombres que constituyen nuestro universo aconseja no entrar en cálculos estadísticos precisos. El cociente obtenido de dividir el número de concurrencias por el de veces en que se proveyó el oficio resultaría engañoso, además, por la inexistencia de candidaturas algunos años en que se optó por la reelección.

46. Vid. APENDICE, Tabla 2.

47. No llegaron a ser incluidos en ninguna terna, pese a haberse ofrecido para ello: D. Juan de Castellví Villanova, D. Pedro Giner, D. Gaspar de Proxita, D. Luis Maza de Lizana y D. Enrique Escorcia y Ladrón, en 1656/57; D. Pedro Sanz, D. Francisco Artés y Muñoz y Dr Hilarión Palmir, en 1663/64; D. Jerónimo Vallterra Blanes y Brizuela, en 1700. (Los memoriales correspondientes, en ACA: CA, leg. 736, exp. 17/6, exp. 17/8-10, exp. 17/11-13; leg. 664, exp. 18/1; leg. 736, exp. 17/15; leg. 759, exp. 7/16, exp. 7/18, exp. 7/5; leg. 857, exp. 70/3, respectivamente). Sí consiguieron formar parte de alguna terna los pretendientes D. Luis Blasco, en 1606; Juan Cascant García de Lassa y D. Guillem Carroz en 1656/57 y D. Francisco Pérez de los Cobos, en 1664 (los memoriales correspondientes, en ACA: CA, leg. 866, exp. 28/1-2, leg. 736, exp. 17/7, exp. 17/8-9; leg. 759, exp. 7/14, respectivamente). 
Valencia, o intentarlo en las Baylías Generales y sus correspondientes Lugartenencias y Receptorías ${ }^{48}$.

Otros candidatos a la plaza oriolana, por el contrario, no solamente fueron incluidos en las ternas sin su consentimiento, sino que -sin aspirar a ello-incluso llegaron a ser elegidos por el Monarca para ejercer el oficio, al ocupar la primera posición de la propuesta del Consejo. Ya en 1588 el Consejo ponía en conocimiento de Felipe II una carta del Virrey en que informaba «que don Alonso Çanoguera se ha escusado de acceptar el govierno de Orihuela por diferentes razones que don Alonso refiere en un papel»; al tiempo que elevaba nueva consulta proponiendo en su lugar a D. Alvaro Vique como el más a propósito para cubrir ese vacío ${ }^{49}$. También D. Felipe Boil tuvo que excusarse, en 1664, alegando motivos de salud, cuando tuvo conocimiento de que había sido agraciado con el mando de la Gobernación de Orihuela, obligando con ello al Consejo a elaborar nueva terna ${ }^{50}$. En 1673 era D. Francisco Valls y Castellví quien, al recibir noticia de su reciente designación, dirigía misiva al Vicecanciller de la Corona de Aragón asegurando no estar en condiciones de aceptar el cargo y, por consiguiente, lamentando «que a los deseos con que me allo de servir a Su Magd no acompañe mi caudal, que este es presisso para autorizar tan gran puesto quando el salario es tan corto que no a habido Governador que no quedase destruido y no hallándome con medios para poder empeñarme a azetar este empleo me sirve de gran mortificación haver logrado tan gran dicha....por ser excesiva assi para mi capacidad como para mi asienda y salud, que esta la gozo arto limitada $\rangle^{51}$. Y esta situación volvería a repetirse cinco años más tarde, cuando, por motivos algo distintos, D. Juan de Cardona, al serle comunicada su designación, alegaba tener que ocuparse de la administración de una herencia recibida de sus suegros, en la que habían de suceder sus hijos, «por justa disculpa para escusarme deste empleo, en que tan honrrado quedaba, pero tan desacomodado en esta hacienda $\rangle^{52}$. En las cuatro ocasiones mencionadas, a los agraciados que rehusaron hacer efectivo el nombramiento les fue aceptada la renuncia, sin que llegara a expedirse el privilegio acreditativo. El servicio a la Corona en este tipo de empleos adquiría así una dimensión de voluntariedad que excluía cualquier incontestable imposición. Las obligaciones que recaían sobre los súbditos, y particularmente de los del estado noble, de prestar auxilium y consilium al soberano, encontraba aquí unos límites difíciles de traspasar.

48. Vid. Gandoulphe, Pascal: Au service du Roi. Institutions de gouvernement et officiers dans le Royaume de Valence, 1556-1624, Montpellier, 2006.

49. ACA: CA, leg. 651, exp. 32, consulta del Consejo de Aragón, de 17 de diciembre de 1588.

50. ACA: CA, leg. 759, exp. 7/11, consultas del Consejo de Aragón, de 20 de junio y de 15 de julio de 1664.

51. ACA: CA, leg. 784, exp. 19, memorial de D. Francisco Valls y Castelví, de 30 de mayo de 1673.

52. ACA: CA, leg. 798, exp. 66/1, memorial de D. Juan de Cardona, de 29 de noviembre de 1678. Cardona volvió a ser nombrado en 1685 , hallándose en la corte, y al año siguiente tomó posesión de la plaza D. Jaime Borrás (AMO: Lib. No. 2.033, ff. 250-251v, 185-185v. 
El escaso atractivo que, para determinados sectores de la nobleza, podía suscitar el desempeño del oficio no era ajeno a la insuficiencia de la retribución económica que llevaba asignada; pero tampoco, a las incomodidades que ocasionaba su ejercicio. El salario anexo al mismo consistía tradicionalmente en 600 libras anuales, de las cuales 400 , al estar consignadas sobre la recepta ordinaria, se cobraban sin dificultad, mientras que las 200 restantes, procedentes de la tesorería, resultaban de más insegura percepción. A ellas había que añadir los «gajes» procedentes de las sentencias, que podían ascender a unas 20 libras anuales. Con estos emolumentos el Gobernador tenía que afrontar, en primer lugar, los derechos de expedición del privilegio; a lo que seguía «el gasto de mover su casa», el alquiler de sus dos residencias, en las ciudades de Orihuela y de Alicante, respectivamente, «a que se añaden los gastos de los viajes y asistencias en las dos ciudades y de las salidas que se ofrecen a persecuciones de delinquentes en que no tiene dietas», más los gastos de representación y otros extraordinarios que de continuo «se ofrecen» ${ }^{53}$. El balance final dependía de una serie de elementos, tanto de carácter objetivo y circunstancial -las necesidades que había que atender-como subjetivo -la largueza o austeridad en el modo de vida-; pero no debió ser excepcional que, al final de su mandato, algunos Gobernadores acabaran en peor situación financiera que la que habían disfrutado en el momento de jurar el cargo. Aunque los motivos seguramente fueron muy distintos a los expresamente señalados, al tomar posesión de la plaza D. Luis Ferrer en 1626 aseguraba «que por muerte de don Juan Ferrer su padre, Gobernador que fue del mismo gobierno, a quedado con muchas deudas en muchas cantidades causadas en el real servicio de Vra. Magd $\rangle^{54}$.

Las solicitudes de recompensas y jubilaciones con asignaciones económicas formaban parte, por otro lado, del discurso habitual de quienes se consideraban merecedores de ello por los -impagables- servicios prestados a la Corona, los sinsabores soportados y las quiebras experimentadas en hacienda y salud que tal dedicación, ejecutada con el debido celo, comportaba, La peculiar «economía de la gracia» que regía las relaciones entre servicios y mercedes exigía la restauración de algún tipo de equilibrio entre ambas ${ }^{55}$. Y, sin duda, en muchos casos se cargaban las tintas en exceso con ánimo de provocar la esperada compasión regia, que habría de traducirse en una gratificación compensatoria.

Tras cuarenta y cuatro años de servicio a la Corona -los veinte últimos como Gobernador de Orihuela-, en 1607 D. Alvaro Vique solicitaba licencia para retirarse y una serie de mercedes: «ayuda de costa sobre la deuda de cinco mil ducados que se han de cobrar en Alicante», «el oficio de credenciero de la dicha ciudad de Orihuela para sí y sus descendientes, que le pueda servir por substituto que sea de confianza, el qual dicho officio vale ducientos y veinte ducados», "alguna pensión sobre el Obispado de Mallorca para Don Alvaro Vique su hijo, con que pueda seguir sus estudios, y en

53. ACA: CA, leg. 790, exp. 10/5, memorial de la ciudad de Alicante, de 22 de mayo de 1667.

54. ACA: CA, leg. 874, exp. 95, memorial de Don Luis Ferrer de Proxita, sin fecha.

55. HeSPANHA, Antonio Manuel: «La economía de la gracia», art. cit. 
el interim...se le pague en su casa el sueldo de su cargo, que es seiscientos escudos, como se ha hecho con otros». De este modo quedaría «con la reputación y galardón que merecen los gastos y trabajos», pues «en esto he acabado de consumir la poca hacienda que me quedaba de mi patrimonio y he perdido mi salud de suerte que no puedo acudir a las obligaciones de mi cargo ${ }^{56}$. Dada la cortedad de los emolumentos del oficio, en relación con los dispendios y la dedicación que exigía su desempeño, también el Virrey subrayaba esta faceta pública -en lo que tenía de ejemplar- de la compensación mediante la concesión de mercedes: «para que todo el mundo viese y entendiese la que V. Magd. da a los que como el han cumplido con sus obligaciones $\rangle^{57}$

Y tampoco las ciudades de Orihuela y Alicante consideraban que el oficio de Gobernador estaba bien retribuido, de modo que en 1667 solicitaron un aumento salarial para elevar la estimación y dignidad del mismo «porque el (salario) que tiene es tan tenuo que se consume en la conducsion de su casa y después de gastar de propios y con esto sesara la escusacion que las personas de la esfera pide cargo tan grande podrán procurar» ${ }^{58}$. Aunque la retribución no se había modificado al menos desde el siglo anterior, la Corona estimó «no dar lugar el estado de la Real Hacienda a estas cargas», pero trató de implicar directamente a ambas ciudades, por si «pudieran contribuir con alguna cantidad proporcionada para el aumento del salario conforme a lo que ellos mismos desean». El consistorio alicantino respondió entonces al envite aprobando una dotación suplementaria a sus expensas de 200 libras anuales -que la Reina hubo de autorizar expresamente, por no haberse decidido en forma, con arreglo a lo estipulado en estatutos-, "por vía de ayuda de costa....y sin que sirva de exemplar para los demás Governadores». Orihuela, en cambio, tuvo que excusarse argumentando «que las rentas anuas no son bastantes para acudir a los gastos y cargas inexcusables que esta ciudad tiene ${ }^{59}$; afirmación que, no por cierta, dejaba de traslucir quizá una soterrada desaprobación de la gestión de aquél. El Marqués de la Casta vio incrementados de este modo sus emolumentos. Pero no lo tuvo nada fácil su sucesor.

Producida la vacante del oficio de Gobernador, en sesión celebrada el 24 de mayo de 1671 el consell alicantino decidió por unanimidad no solamente retirar la ayuda de costa de las 200 libras anuales con que venía contribuyendo durante el último trienio, -alegando que «al present la Ciutat es trova ab molts ahogos y alcansada per haverli minorat les rentes y ser los temps molts sterils y necessitats》-, sino, además, prohibir que en lo sucesivo pudiera volver a concederse: «ara ni per ningún temps aixi al Governador que succehira al dit Marques com als que succehiran no puxa donar ni done este Illustre Consell la dita ajuda de costa de doscentes lliures annuals pero ni altra alguna major ni menor sub nullitatis decreto». No obstante la antecedente reso-

56. ACA: CA, leg. 701, exp. 48/5, 82/1; leg. 866, exp. 88/2, memoriales de D. Alvaro Vique y Manrrique, de 4 de octubre y 6 de noviembre de 1607 y sin fecha.

57. ACA: CA, leg. 701, exp. 82/2, informe del Virrey, de 6 de noviembre de 1607.

58. ACA: CA, leg. 790, exp. 10/3, memorial de la ciudad de Orihuela, de 21 de mayo de 1667. Los de la ciudad de Alicante, de 22 de mayo y 27 de junio del mismo año, en exp. 10/4-5.

59. Ibidem, exp. 10/3-9, documentos varios sobre el tema, entre mayo de 1667 y febrero de 1668. 
lución consiliar, en cuanto el nuevo Gobernador, D. Francisco Calatayud y Villarrasa, experimentó las dificultades para mantenerse con el salario ordinario, sondeó las posibilidades de incrementarlo, teniendo en cuenta el precedente sentado con respecto al Marqués de la Casta. En mayo de 1672 el consistorio alicantino no tuvo reparos en dirigirse al Consejo de Aragón solicitando para aquél el aumento retributivo necesario, pero esta vez a cargo de las rentas del Real Patrimonio, pues «son bien pingues en esta Governacion». Como la respuesta fuera, una vez más, que «el estado de aquella Recepta no permite esta carga», D. Francisco solicitó directamente a la Corona permitiese a la ciudad portuaria - posiblemente, ahora, sin contar con ella- volver a lo practicado con su predecesor. Así lo hizo la Reina, en agosto de 1672, eximiendo a la ciudad de atenerse al procedimiento regulado en estatutos para su aprobación. Pero cuando el tema tuvo que tratarse en el consell -el 27 de noviembre- surgieron discrepancias que impidieron adoptar cualquier decisión; hasta que en otra sesión posterior -celebrada el 25 de marzo de 1673- se impuso claramente el criterio contrario a participar en retribución alguna. Precisamente unos días antes había fallecido D. Francisco y lo que entonces se dilucidaba era la estrategia a seguir en relación con las hipotéticas aspiraciones salariales del sucesor en el oficio. Para evitar que en adelante volviera a replantearse el tema de las ayudas de costa, el consell aprobó por unanimidad varios capítulos y ordenanzas que las prohibían expresamente. Pero las presiones de la Corona para conseguir la participación de la hacienda municipal alicantina en la retribución del Gobernador no cesaron, hasta el punto de llegar a «suspender la confirmación» de esas nuevas ordenanzas ${ }^{60}$.

Con todo, parece improbable que durante el trienio siguiente se suscitara nuevamente la necesidad de aumentar los emolumentos del oficio, a pesar de que el primer designado para ocuparlo -D. Francisco Valls- expresó de inmediato su renuncia. El Consejo era consciente de que el tema económico no carecía de importancia en la provisión del cargo, pues en consulta de 30 de mayo indicaba «que pues D. Francisco Valls se ha escusado por faltarle medios, tampoco lo aceptara D. Antonio Carroz, propuesto por el Virrey en primer lugar, por hallarse mucho mas desacomodado que D. Francisco Valls. Y que assi podría servirse Su Magd de nombrar a D. Miguel Fenollet, que es caballero de conocida calidad y acomodado de hazienda ${ }^{61}$. Vacíos documentales impiden conocer en qué medida se conformó D. Miguel con las 600 libras acostumbradas. Pero quién -es seguro- intentó incrementarlas fue su sucesor, el Barón de Boil y Borriol.

Al poco tiempo de acceder éste al oficio, en 1676, el consistorio oriolano, apoyando la posición alicantina, exponía al Consejo: «reselamos que el Varon no pueda conservarse en esta ocupación por lo tenuo del salario que de muy antiguo tiene señalado este officio....y siendo este puesto el primero de esta provincia no puede quien le

60. ACA: CA, leg. 790, exp. 10/1-20. El expediente es bastante completo, pues incluye copias de las resoluciones del consell alicantino, cartas del Virrey y de la Reina y consultas del Consejo de Aragón sobre el tema.

61. ACA: CA, leg. 784, exp. 33, consulta del Consejo de Aragón, de 30 de mayo de 1673. 
ocupa portarse con el lustre que le pertenece sin gastar mucho de su patrimonio para sustentarse decorosamente, y ponderado este inconveniente puede ser que en adelante excusen el pedirle sujetos de la graduación del Varon y que descaesca de su antiguo esplendor, porque....haviendo de ser las asistencias de este ministro en país donde muy de ordinario acuden personas de superior gerarquia no es desente que escuse todo el necesario para la representación del puesto». La solución, sin embargo, no podía encontrarse en las exhaustas arcas municipales, ya que se trataba de un oficial real, y puesto que, según estimaban ambas ciudades, «la Real acienda en esta recepta esta hoy mejorada y puede acudir a todos sus cargos, sea de Su Real servicio augmentar el sueldo competentemente al Varon de Boil y Borriol y a los demás Portantvezes que le sucederán». Pero la petición habría de chocar una vez más con el rechazo de la Corona, que nuevamente expresó su negativa a asumir cualquier contribución suplementaria: «No esta la Recepta en estado de poderle añadir nuevas cargas» ${ }^{62}$.

Ni siquiera la comprobación documental de los elevados gastos en que solían incurrir estos servidores regios llegó a mover el ánimo del monarca. En 1686, D. Francisco Guerau y Ciurana presentaba una relación pormenorizada de dietas que se le debían y pagos realizados de su propio bolsillo -no incluídos en su salario- entre junio de 1684 y septiembre de 1685, cuyo reintegro reclamaba a la Corona, que puede servir de muestra para conocer algunos de esos gastos a que ordinariamente solían hacer frente los Gobernadores. A través de un total de 40 partidas contables, pudo certificar ser acreedor a las arcas reales por un montante de 4.080 reales valencianos ${ }^{63}$.

Durante toda la centuria, el salario ordinario del Gobernador no habría de experimentar variaciones; pero algunos de los que ejercieron el cargo a finales de la misma pudieron completar sus ingresos con remuneraciones procedentes de la administración de rentas reales. Así, en 1693 se hizo merced a D. Josep de Borja Llansol, conjuntamente con la titularidad de la Gobernación y las 600 libras de retribución correspondiente, del empleo de «Administrador de los derechos Reales de V.Mgd. en dicha ciudad de Alicante y de las Salinas de la Mata y Orihuela, con el sueldo de trescientos escudos al mes» ${ }^{64}$.

Pese a las escasas posibilidades de medro que, en el terreno económico, ofrecía el cargo -restando atractivo a su desempeño-, la insuficiencia retributiva difícilmente llegó a convertirse, no obstante, en un elemento disuasorio para algunos nobles con voluntad y dotes de mando y con aspiraciones de promoción personal o familiar a través del servicio regio. De hecho, la mayor parte de los que aceptaron el empleo -incluído D. Jaime Borrás, quien en 1686, al serle notificada extraoficialmente su designación por el Virrey, «ha respondido con la atención correspondiente a sus obli-

62. ACA: CA, leg. 790, exp. 10/21, memoriales de las ciudades de Orihuela y de Alicante, de 8 y 3 de mayo, respectivamente, y consulta del Consejo de Aragón, de 18 de mayo de 1676.

63. ACA: CA, leg. 826, exp. 43/1-13, memoriales y presentaciones de cuentas de D. Francisco Guerau y Ciurana e informes de la Junta Patrimonial de Alicante, de octubre de 1686.

64. ACA: CA, leg. 672, exp. 35/3, consulta del Consejo de Aragón, de febrero de 1696. 
gaciones sacrificándose con total resignación ${ }^{65}$ - no tuvieron reparos en continuar en su ejercicio durante otro trienio suplementario. De los ocho Gobernadores que llegaron a ejercer su trienio correspondiente durante la segunda mitad del siglo XVII, cinco obtuvieron la reelección por otro periodo similar; y, de los tres casos restantes, uno -D. Francisco de Calatayud, en 1673- falleció mientras lo ejercía; otro, -D. Miguel de Fenollet, en 1675- fue acusado y residenciado y, aunque no se obtuvieron pruebas contundentes, removido al oficio de Lugarteniente de Gobernador de Valencia ${ }^{66}$; y del tercero -D. Pedro Boil y Borriol, en 1679-, desconocemos las razones por las que no se les renovó.

La reelección se convirtió, así, en práctica habitual, al considerarse que un periodo de sólo tres años resultaba demasiado corto para compensar el esfuerzo y sinsabores que requería el cambio de vida operado y la adaptación a un nuevo entorno social y material. Al contemplarse la posibilidad de prórroga se contribuía, además, a estimular en el agraciado la dedicación y el celo puesto en el ejercicio de su función, con la recompensa de una futura renovación de la confianza depositada en su labor.

En el origen de esta práctica y en su desarrollo posterior, el papel de las dos ciudades que compartían la presencia del Gobernador no fue desdeñable. En la primera ocasión en que se produjo vacante por cumplimiento del plazo estipulado -en 1660-, el consistorio oriolano se apresuró a exponer ante el Consejo de Aragón «el asierto con que Don Diego Sans de la LLossa govierna» para solicitar «confirmarle otro trienio en este govierno acabado el que oy sirve porque estamos tan bien hallados con la prudensia y buen selo de este sujeto y nos prometemos que proseguirá su gobierno con la misma enteresa que hasta ahora ${ }^{67}$. Dos meses más tarde era el consistorio alicantino el que se dirigía también al Consejo, pero en esta ocasión para recordarle la disposición de cortes de 1645, que establecía su duración trienal, y que «por ser esta la primera vez en que se a de executoriar este auto... tendrá previstos los inconvenientes que de confirmarle pueden resultar» ${ }^{68}$. Tampoco el asesor de la Gobernación -el Dr. Hilarión Palmir, obligado contra su voluntad a aceptar la jubilación- consideraba conveniente la prorrogación del mandato, pero en este caso por el mal comportamiento de D. Diego al frente del oficio, contra quien lanzaba varias acusaciones en un extenso informe. Finalmente, habría de resultar decisiva la valoración del Virrey, quien, reafirmando la favorable opinión que ya tenía del Gobernador -pues solo encontraba una pequeña mancha negra en un lance ocurrido días atrás, por conflictos jurisdiccionales con el Bayle y el Justicia de Orihuela-, atribuía la posición alicantina precisamente al celo con que había administrado la justicia durante su trienio «encontrándose con algunas personas poderosas, cosa muy sensible en Alicante, por lo poco que aman la justicia»; al tiempo que explicaba la animadversión del asesor «por el sentimiento de su jubila-

65. ACA: CA, leg. 825, exp. 1/1, informe del Virrey, de 25 de junio de 1686.

66. AHN: Consejos, leg. 18.461, Informe de D. Jaime Madroño sobre las acusaciones contra D. Miguel Fenollet, en Valencia, a 21 de abril de 1676.

67. ACA: CA, leg. 750, exp. 2/1, memorial de la ciudad de Orihuela, de 17 de agosto de 1660.

68. Ibidem, exp. 2/10, memorial de la ciudad de Alicante, de 17 de octubre de 1660. 
ción», debida en parte a los desfavorables informes que había vertido D. Diego sobre el letrado. Proseguía el Virrey haciendo ver «que en el auto de Corte no hay prohibición de que V. Magd. prorrogue los Governadores», para acabar recomendando la práctica de la reelección para quienes lo hubieran merecido como forma de atraer candidatos, «pues no son sobrado relevantes los sujetos que salen a la pretensión deste Gobierno, $\mathrm{y}$ viendo que no es trienal de precisso, podrá ser se alienten otros en que tenga mayor conveniencia el servicio de V. Magd., que por el trienio solo no se alientan a dejar sus casas $\rangle^{69}$.

Una vez sentado el precedente -pues D. Diego Sans de la Llosa fue, efectivamente, prorrogado en el cargo, sin necesidad de terna, al hacer suyo el Consejo el informe del Virrey ${ }^{70}-$, los demás Gobernadores tampoco tuvieron muchas dificultades para continuar ejerciendo durante un segundo trienio; mientras que la posibilidad de llegar a un tercero fue implícitamente descartada ya en 1664, al cumplir D. Diego su segundo mandato consecutivo ${ }^{71}$.

Ante la eventualidad de una posible reelección, las ciudades solían tomar la iniciativa, dando su parecer sobre la conveniencia de continuar con esta práctica. Mas no siempre los apoyos fueron unánimes. En mayo de 1667, Orihuela y Alicante coincidieron en solicitar prórroga para el mandato del Marqués de la Casta, al tiempo que - como ya se da dicho- un incremento de su retribución, con el resultado anteriormente mencionado. No obstante, de haberse producido esta situación cuatro años atrás, las posiciones quizás no habrían estado tan definidas, pues en marzo de 1663 el consell de la ciudad de Orihuela había determinado que cualquier petición de prórroga para el Gobernador debía contar en adelante con la aprobación expresa de ese órgano asambleario, ya que «esta costando muchos desvelos que el oficio sea trienal y no perpetuo ${ }^{72}$. Esta genérica decisión no parece que llegara a ponerse en práctica, sin

69. Ibídem, exp. 2/9, informe del Virrey, de 18 de enero de 1661.

70. Ibidem, exp. 2/9, consulta del Consejo de Aragón, de 25 de enero de 1661.

71. El segundo mandato de D. Diego cumplía en abril de 1664 y aunque dos médicos de Alicante habían certificado, en diciembre de 1663 y a instancias del regente de la asesoría de la Gobernación en dicha ciudad, su paulatina recuperación «de un accidente que padeció de una perlesía en el lado izquierdo que le privo del movimiento del brazo y de la pierna izquierdos, tan solamente dexandole ilesas las potencias animales principales», nadie planteó la posibilidad de nueva reelección, comenzando por la ciudad de Orihuela y por el Virrey, que le había favorecido tres años atrás. (ACA: CA, leg. 759, exp. 7/1-17, documentos varios sobre el tema). Y menos aun la ciudad de Alicante, que, si ya había informado desfavorablemente en 1660, estaba ahora siendo objeto de una visita de residencia, a instancia precisamente de D. Diego. Sobre esta visita, DiEz SANCHEZ, Marta: «La visita de residencia como instrumento de control de la Monarquía sobre el municipio foral: El caso de Alicante», en FERNÁNDEZ ALBALADEJO, Pablo (ed.): Monarquía, Imperio y Pueblos en la España Moderna, C.A.M.-Universidad de Alicante, A.E.H.M., Alicante, 1997, pp. 561-568.

72. AMO: Contestador de 1663, ff. 152-153, sesión del consell de la ciudad de Orihuela, de 5 de marzo de 1663. 
embargo, cuando cuatro años más tarde se presentó la ocasión, al expirar el primer trienio del Marqués de la Casta ${ }^{73}$.

La resolución adoptada por el consell oriolano en 1663 tuvo su paralelismo en otra parecida, pero de contenido aun más radical, aprobada por el órgano asambleario de la ciudad vecina ocho años más tarde. Así, en sesión celebrada el 24 de mayo de 1671, el consell de Alicante decidió, además de retirar la ayuda de costa que venía otorgando al titular del oficio - a partir de la próxima vacante-, «que en observancia del acte de cort del any 1645 que dispon que lo Governador desta Governacio sia trienal....que este Illustre Consell ni los Magnifichs Justicia y Jurats ni altre en nom de la present Ciutat no puxen escriure ni escriguen per a que es continue Governador algu que ara y despres succehiran per mes temps que el que dispon dit acte de cort....y que finit lo primer trieni de qualsevol Governador escriguen y supliquen a Sa Magd. com a qui convinga que se observe dit acte de cort y no es continue en altre trieni si que es fasa nova provisio en diferent subjecte» ${ }^{74}$.

Las iniciativas conciliares emprendidas en Orihuela y Alicante en torno a la cuestión de las prórrogas en el mandato de los Gobernadores expresaban seguramente la recuperación del protagonismo asumido por estos órganos asamblearios y representaban un toque de atención a la excesiva independencia con que actuaba el órgano ejecutivo del consistorio, integrado por el justicia y los jurados. Pero más que la tendencia de éstos a contemporizar con los poderes externos al municipio, e incluso de buscar su aplauso, era la apropiación de los resultados de esa práctica política desarrollada por el ejecutivo local -esto es, los beneficios personales que podía reportar a quienes ocupaban transitoriamente aquellas magistraturas-, lo que molestaba a la oligarquía que formaba parte del consell. Al ser todos los cargos consistoriales -incluidos los 40 escaños del consell, en una y otra ciudad- de renovación anual y extraídos por sorteo de una base de reclutamiento común y restringida, no había diferencias sustanciales entre quienes ocupaban los oficios directivos y los miembros del consell. La oligarquías municipales no constituían, empero, bloques totalmente homogéneos, de modo que podían aparecer fisuras que solían reflejarse en la frecuente disparidad de criterios expresados en algunos debates del consell. Por consiguiente, las resoluciones contrarias a la prorrogación de los mandatos de los Gobernadores, aunque contaron en ambos casos con la unanimidad de los respectivos consells, no tenían por qué ser necesariamente definitivas. Así se explica que, nuevamente en 1682, la ciudad de Orihuela se dirigiera al Consejo de Aragón proponiendo la reelección de D. Francisco Guerau

73. La retirada, por parte de Orihuela, de la propuesta de aumento de sueldo, en caso de que tuviera que ser a sus expensas, expresada en 6 de agosto de 1667, difícilmente puede considerarse indicio de la aplicación de aquella resolución consiliar. ACA: CA, leg. 790, exp. 10/8, memorial de la ciudad de Orihuela, de 6 de agosto de 1667.

74. ACA: CA, leg 790, exp. 10/19, copia del acta de la sesión del consell de la ciudad de Alicante, de 24 de mayo de 1671. 
y Ciurana ${ }^{75}$. Y, aunque no disponemos de datos para 1697, la prórroga obtenida este año por D. Josep de Borja y Llansol difícilmente pudo salir adelante sin algún informe favorable procedente de una de las dos ciudades cuyas posiciones al respecto solían tenerse en cuenta.

Si las actuaciones de los Gobernadores durante el trienio que inicialmente tenían asignado podían resultar determinantes a la hora de decidir la prorrogación de su mandato por otro periodo similar, las desarrolladas con anterioridad a su nombramiento tampoco podían ser totalmente ignoradas en el proceso de reclutamiento. Los requisitos que debían reunir los agraciados no estaban especificados en normativa alguna; probablemente, salvo la condición de ser natural del Reino o, en momentos de excepcionalidad - por situaciones de bandolerismo extremo o graves alteraciones de la paz social-, de la Corona de Aragón, tal como establecían las disposiciones forales ${ }^{76}$. Es por ello que, cuando, en 1553, el príncipe Felipe designara al abulense D. Nuño del Aguila, fuera inmediatamente persuadido a rectificar, a instancias del consistorio oriolano, que le hizo ver el contrafuero en que incurría tal decisión ${ }^{77}$. Pero la ausencia de más requisitos explícitos no impedía que, de forma tácita, resultaran habitualmente operativos otros criterios selectivos, como puede deducirse del análisis de los rasgos comunes observables en el personal del que se nutrió el oficio, e incluso del que aspiró a ocuparlo.

Como fácilmente puede suponerse, la pertenencia al estamento militar fue, en este sentido, una condición compartida no solamente por los 23 Portantveus que ejercieron en Orihuela, sino también por la treintena larga de candidatos identificados que nunca llegaron a obtener la plaza. En la lógica del sistema de poder de la época, resultaba impensable que los llamados a ejercer la jurisdicción real en tan elevado puesto no contaran con esta condición estamental. Pero, dentro de la nobleza valenciana, eran varias las categorías que podían distinguirse; y no todas se hallaban representadas por igual entre los titulares del oficio. Los simples caballeros, por ejemplo -fueran de inmemorial o de privilegio-, al constituir el estrato inferior del estamento, apenas tuvieron opciones de acceder al cargo; aunque no faltaron quienes lo intentaron ${ }^{78}$. Para hacerse respetar por los señores de vasallos del distrito, mantener la autoridad sobre las oligarquías municipales, pero también sobre las cuadrillas de bandoleros y demás «facinerosos», y dirigir el mando militar se precisaba personal de mayor rango social; de modo

75. ACA: CA, leg. 814, exp. 35/1, consulta del Consejo de Aragón, de 26 de mayo de 1682. No obstante, en este caso hay constancia de que se solicitó -y se elaboró- terna al Virrey y al Consejo

76. TARAÇONA, Pere Hieroni: Institucions dels furs y privilegis del Regne de Valencia, Imp. por Pere de Guete, Valencia, 1580 (ed. facsímil, Librerias Paris-Valencia, Valencia), p. 29.

77. Vid. supra, nota 20.

78. En realidad, solo he podido detectar los casos de Juan Cascant García de Lasa, pretendiente en 1656 y en 1658; y de Juan Pertusa, en este último año y en 1664, pues en la candidatura de 1671 figura ya con el don. 
que fue entre la nobleza propiamente dicha, con privilegio para usar el tratamiento de don, donde se reclutó la totalidad de los Portantveus de Orihuela ${ }^{79}$.

Y muy pocos de esos nobles añadieron a esta condición la posesión de título específico, pues aunque a lo largo del siglo XVII se fue prodigando este tipo de concesiones entre la nobleza valenciana ${ }^{80}$, solo se detecta un conde -el de Almenara, en la persona de D. Luis Ferrer y de su hijo D. Juan - y un marqués -el de la Casta- entre los agraciados con el oficio - ya que el tratamiento de barón solo denota en Valencia rango jurisdiccional de mero y mixto imperio-; mientras que otros dos titulados - El Conde de Ana y el Conde de Casal- solo llegaron a figurar en las ternas virreinales o del Consejo de Aragón. Si a ello se añade la total ausencia de los sectores más encumbrados, como era el caso de los Duques - por otra parte, muy escasos en Valencia- la base social de reclutamiento de los Portantveus se correspondería, aproximadamente, con los sectores intermedios o, como mucho, medio-altos del estamento.

Pese a la unánime condición nobiliaria de que gozaban, ha de anotarse, por otro lado, la relativamente escasa presencia de señores de vasallos entre los Portantveus de Orihuela, que contrasta con la enorme extensión que llegó a tener el régimen señorial en todo el Reino ${ }^{81}$. Incluídos los dos titulados mencionados -el Conde de Almenara y el Marqués de la Casta-, a los que hay que añadir D. Pedro Boil, baron de Borriol, seguramente no pasaron de la media docena los poseedores de dominios jurisdiccionales, del total de 23 individuos que ejercieron el cargo ${ }^{82}$. La condición señorial no fue, por tanto, uno de los méritos decisivos en la provisión del oficio. Y tampoco estuvo demasiado extendida entre esos 38 candidatos frustrados que he podido identificar, pues solo seis de ellos adujeron ser señores de vasallos -D. Felipe Boil, Sr. de Manises; D. José de Calatayud y Pallás, Sr. de Agres; D. Francisco Artés y Muñoz, Sr. de Ayodar y de la Tenencia de Villamur; Juan Pertusa, Sr. de Vinalesa; además de los Condes de Anna y de Casal-; a los que hay que añadir otros dos primogénitos que, seguramente, acabarían heredando los dominios jurisdiccionales paternos: D. Guillem Carroz, del Conde de Cirat, y D. Gaspar de Proxita, del Conde de Almenara. La incidencia de las jurisdicciones señoriales entre los activos patrimoniales de los Portantveus de Orihuela no parece superar la media aplicable al grupo nobiliario valenciano, en general; y quizá

79. Sobre las diversas categorías en el seno del estamento militar, vid. MADRAMANY Y CALATAYUD, Mariano: Tratado de la Nobleza de Aragon y Valencia comparada con la de Castilla, Imp. Por Josep y Tomas de Orga, Valencia, 1788 (ed. Facsímil, ed. Paris-Valencia, Valencia, 1985), pássim.

80. Vid. PAstor FluiXÀ, Jaume: «Nobles i cavallers al País Valencià», Saitabi, XLIII, Valencia, 1993, pp. 13-54.

81. Sobre esta cuestión, GIL OLCINA, Antonio: La propiedad señorial en tierras valencianas, Del Cenia al Segura, Valencia, 1979; CASEY, James: El Regne de València al segle XVII, Curial, Barcelona, 1979, pp. 119 y ss.; ARDIT LUCAS, Manuel: Els homes i la terra al Pais Valencià, Curial, Barcelona, 1993, vol. I, pp. 79-105.

82. En realidad, solo tengo constancia indirecta - pues no solían intitularse como tales- de la posible condición señorial de D. Pedro Maza de Lizana Carroz, que lo era de Mogente (ESCOLANO, Gaspar: $O p$. cit., p. 653), de D. Juan Quintana, Sr. de Enova; y de D. Alvaro Vique y Manrique, Sr. de la baronía de Laurín (BELLOT, Pedro: Op. cit. II, p. 88). 
llegó a tener alguna relación con el perfil ideal buscado por la Corona para los ocupantes de la plaza. Así, cuanto menos implicaciones directas en la salvaguardia de los intereses jurisdiccionales de los señores tuvieran estos altos oficiales, más fácil y efectiva podía resultar la defensa de las posiciones regias en la administración del territorio de la Gobernación, que tenían expresamente encomendada.

Entre las cualidades honoríficas que adornaban la figura y el rango de esta nobleza de servicio, la posesión de un hábito militar, aunque elemento digno de encomio, tampoco parece que llegara a alcanzar una consideración determinante. La información disponible al respecto quizá no sea lo completa que sería deseable, pero no deja de ser significativo que frente a los diez caballeros de hábito -6 de la Orden de Montesa y 4 de la de Santiago- contabilizados entre los otros 38 candidatos $^{83}$, sólo haya constancia de seis entre los 23 titulares de la Gobernación: D. Juan Quintana, D. Alvaro Vique y Manrique, D. Luis Ferrer y Calatayud, D. Gerardo Ferrer y Proxita, D. Jaime Antonio Borrás y D. Josep de Borja Llansol. La concentración cronológica de la mayor parte de estos caballeros de Ordenes - titulares y candidatos de la plaza de Gobernador- en el siglo XVII es claro indicio, por otra parte, de la creciente aspiración a la obtención de este privilegio honorífico por parte de la nobleza hispana, en general, que no podía dejar de afectar a los sectores concretos de los que se nutría el oficio de Portantveus de Orihuela ${ }^{84}$. Su posesión fue, efectivamente, mérito exhibido con frecuencia por los candidatos a esta plaza en los memoriales explicativos de sus curricula; y, al elevar la consideración social del pretendiente, pudo granjearles algún beneficio suplementario. Pero, en general, no parece que llegara a convertirse en requisito decisivo que determinara su elección para el desempeño del oficio.

Frente a la condición señorial y a la posesión de hábito de órdenes, la experiencia en el campo militar, en cambio, sí pareció obrar efectos más favorables; sobre todo, si había conducido a la consecución de un puesto de mando de tropa de mediana relevancia. Conocedores de la importancia de la vertiente castrense del oficio de Portantveus, la mayor parte de los candidatos que aspiraron a ejercerlo contaban con experiencia previa en alguno de los diversos frentes bélicos que, a lo largo del periodo considerado, estuvieron al alcance del estamento. Contrariamente, aquéllos que no podían exhibir una mínima dedicación militar tuvieron mayores dificultades para hacer valer su candidatura.

Los amplios servicios prestados al Emperador en el terreno militar por D. Guillem de Rocafull fueron decisivos en su designación para la plaza de Orihuela, según refie-

83. Eran caballeros de la Orden de Montesa: D. Luis Blasco, D. Guillem Carroz, D. Enrique Escorcia y Ladrón, D. Francisco Despuig, D. Antonio Carroz y D. Jerónimo Vallterra. De la Orden de Santiago: Juan Cascant García de Lasa, D. Pedro Giner, D. Francisco Artés y D. Francisco Pérez de los Cobos. Para las referencias documentales, vid. supra, nota 45.

84. La ausencia de información disponible sobre posibles candidatos a la plaza oriolana para el siglo XVI obliga a rebajar la aparente contundencia de esta afirmación. Vid. un planteamiento general, en POSTIGO Castellanos, Elena: Honor y privilegio en la Corona de Castilla. El Consejo de las Órdenes y los Caballeros de Hábito en el siglo XVII, Valladolid, 1988. 
re Escolano ${ }^{85}$. Y tampoco su antecesor en el cargo, D. Ximén Pérez Pertusa, carecía de experiencia en el campo de batalla, como había tenido ocasión de exhibir durante la revuelta agermanada, precisamente junto a su predecesor, el recién nombrado D. Pedro Maza ${ }^{86}$. Antes de servir al rey Prudente como paje durante un quinquenio, D. Alvaro Vique y Manrique se había empleado «diez y seis [años] de soldado Alferez y Capitan, hallándosse en jornadas y occassiones importantissimas $\gg{ }^{87}$. Y su sucesor en la Gobernación, D. Juan Ferrer y Proxita, aseguraba en 1613 haber servido «en Oran, en las galeras de España y en los officios de Capitan de Cavallos de la costa del Reyno de Valencia ${ }^{88}$. Tras el periodo de sucesión hereditaria en el oficio por el linaje Ferrer, el primer Portantveus designado para un trienio, D. Luis Ferrer Aragón y Apiano, era en el momento de su nombramiento, en 1656, «Maestre de Campo de Infantería Española por V. M. en los Reales Ejércitos de Cataluña», luego de una larga y acreditada trayectoria castrense, pues «ha mas de 22 años continuos que esta sirviendo a V.M. siempre en guerra viva hallándose en todas las ocasiones que en dicho tiempo se han ofrecido, assi en el Estado de Milan, como en España, sitio de Traiguera, Tortosa, Barcelona, Girona, y otras plazas ${ }^{89}$. Sucedió al anterior D. Diego Sanz de la Llosa, quien ya en su primera pretensión al cargo, en 1656, tras enumerar los servicios militares de sus antepasados, relataba los propios, «siendo uno de los caballeros que el año 1641 salieron de Valencia a la frontera de Cataluña, asistiendo al Duque de Medinaceli y después fue de los primeros que se embarcaron para el socorro de Tarragona, procediendo en esta occasion con el valor que pedían las obligaciones de su sangre; y después salió acompañando al Conde de Oropesa a la frontera de Cataluña para el socorro de Tortossa, sirviendo en todas estas jornadas a su costa» ${ }^{90}$.

La proximidad temporal del conflicto catalán e incluso de la Guerra de los Treinta Años hizo que otros aspirantes al oficio en las vacantes producidas en 1656 y 1658 también expusieran sus hojas de servicios acreditados en los diferentes campos de batalla, desde Flandes a Italia, pasando por Francia y por las casi omnipresentes frontera catalana y litoral valenciano. Nobles como D. Luis Blasco, D. Guillem Carroz, D. Juan de Castellví Vilanova, D. Pedro Giner, D. Gaspar de Proxita, D. Enrique Escorcia y Ladrón, D. Luis Maza de Lizana, y D. Antonio Carroz relataron en sus correspondientes memoriales, a veces con profusión de detalles, valerosas hazañas protagonizadas en tierras lejanas o más modestas actuaciones en la defensa de la costa ${ }^{91}$.

85. EsCOLANO, Gaspar: Op. cit., pp. 532-533

86. Ibidem, p. 693.

87. ACA: CA, leg. 866, exp. 88/2. Memorial de D. Alvaro Vique y Manrrique, antes del 2 de octubre de 1607; otro parecido, en 4 de octubre del mismo año (leg. 701, exp. 48/5).

88. ACA: CA, leg. 633, exp. 2/5, consulta del Consejo de Aragón, de 27 de junio de 1613

89. ACA: CA, leg. 736, exp. 17, memorial de D. Luis Ferrer Aragón y Apiano, anterior al 24 de mayo de 1656

90. ACA: CA, leg.736, exp. 17/16, memorial de D. Diego Sanz de la Llosa, de 1656.

91. Las referencias documentales en supra, nota 47. 
Durante las décadas de 1670 y 1680, de menor intensidad bélica en los tradicionales ámbitos de operaciones, se reducen las noticias sobre esta vertiente militar de los nobles que pretendieron el oficio de Portanveus de Orihuela, e incluso de los que llegaron a obtenerlo. Pero difícilmente puede ser indicio de una posible relegación de esta faceta de su perfil. Un real decreto de 1677 estableció precisamente la preferencia de los militares en las consultas del Consejo de Aragón para la provisión de las plazas de gobierno en general ${ }^{92}$. Y, en el caso que nos ocupa, destaca la larga trayectoria militar de D. Josep de Borja Llansol, quien ya en 1671 pretendiera la plaza, con sólidos argumentos castrenses. Los méritos entonces aducidos resultaron insuficientes, no obstante, para el fin que perseguía; pero fueron bastante mejorados cuando 22 años más tarde, volviera a intentarlo; obteniendo en esta ocasión el premio que entonces se le negó. Llegado el momento de solicitar prorrogación en el oficio por otro trienio, el anciano Portantveus exponía en 1696 «que ha cinquenta y tres años que sirve continuadamente a V.M; los nueve primeros de Page de Guion del Señor Rey Dn. Phelipe Quarto (que esta en el Cielo) y los quarenta y quatro siguientes en Guerra viva por Mar y Tierra; de Capitan de Cavallos Corazas en el Estado de Milan; de Reformado en Estremadura, en el Regimiento de la Guardia, y en Cataluña, en la Armada Real, de Maestre de Campo de un tercio de Infanteria Española, de Governador de Menorca y Lerida, y últimamente de Sargento General de Batalla y Governador de Barcelona; de donde fue V.M. servido mandarle pasar a los Goviernos de Orihuela y Alicante...con el carácter de Maestre de Campo Generalı ${ }^{93}$. Las guerras con Francia y, más concretamente, en este contexto, el destructivo bombardeo a que fue sometida la ciudad de Alicante en 1693, aconsejaban valorar la experiencia y capacidad militar de los Portantveus sobre cualquier otra consideración. Y razones de este tipo también estuvieron presentes al doblar la centuria.

Así, para cubrir la vacante producida en 1700 por fallecimiento de D. Josep de Borja Llansol, al menos dos de los tres integrantes de la terna remitida por el Virrey contaban con acreditada experiencia militar. Al tercero de la lista, D. Sebastián Pertusa, le avalaba especialmente el «que ha servido a V.M. once años que ha sido Capitan de Infantería vivo y reformado en los ejércitos de Cataluña y Milan y en todo lo que se ha ofrecido en el Reyno de Valencia». Finalmente, habría de resultar elegido D. Vicente Falcó y Blanes, al coincidir la valoración del Consejo -y de Su Magestad-con la propuesta virreinal, que le había situado encabezando la lista. En la consulta correspondiente, el Consejo estimó oportuno recordar que no era la primera vez que D. Vicente concurría al oficio, pues ya el anterior Virrey le había colocado en segundo lugar en la terna de 1692, por «haver servido algún tiempo en el exercito de Cataluña y ser muy inteligente en la fortificación $»^{94}$.

92. Vid. GIL PUJOL, Xavier: «La proyección extrarregional de la clase dirigente aragonesa en el siglo XVII», en VV.AA.: Historia social de la administración española. Estudios sobre los siglos XVI y XVII, CSIC, Barcelona, 1980, p. 41.

93. ACA: CA, leg. 672, exp. 30/2, memorial de D. Josep de Borja Llansol, de 16 de enero de 1696. 94. ACA: CA, leg. 857, exp. 70/1, consulta del Consejo de Aragón, de 19 de agosto de 1700. 
Ciertamente, no faltaron ocasiones para acumular méritos en la carrera militar durante el último tercio de la centuria -como lo prueban algunas de las trayectorias vitales que se acaban de exponer-; pero el ideal de servicio a la Corona en el seno de amplios sectores de la nobleza también se expresaba -quizá de forma creciente- a través de otras modalidades. Una de ellas fue el desempeño de altos cargos en la administración real. Y, entre los oficios que se consideraron antesala del de Portantveus de Orihuela, cualquiera de las Lugartenencias del sistema de la Gobernación podía resultar un trampolín apropiado para obtener una posterior promoción. Esta vía tenía el inconveniente, no obstante, de la duración temporal, pues al tratarse estas Lugartenencias de cargos ejercidos, por lo general, sin plazo prefijado, la mayor parte de las vacantes que generaban tenían por causa la defunción, la jubilación o la renuncia. Abandonar una Lugartenencia de Portantveus no era, por tanto, una situación muy frecuente; a no ser que el ocupante hubiera sido seleccionado para desempeñar más altos cometidos.

D. Alvaro Vique y Manrique llegó a Orihuela en 1588 para hacerse cargo del oficio de Portantveus, procedente de la Lugartenencia de Játiva, donde había ejercido durante tres años ${ }^{95}$. Y algo similar ocurrió varias décadas más tarde, cuando en 1671 tomó posesión del mismo empleo D. Francisco de Calatayud Villarrasa, con una acreditada experiencia ya en las Lugartenencias de Castellón de la Plana, primero, y de Valencia, después, donde se estaba empleando a fondo, debido a los achaques de salud y avanzada edad del titular de la capital ${ }^{96}$. Son los dos únicos ejemplos conocidos de promociones de esta naturaleza, pues aunque en 1656 estuvo a punto de alcanzar la misma plaza quien entonces desempeñaba precisamente la Lugartenencia de la ciudad del Segura -D. Juan Cascante García de Laza-, llegando a encabezar varias ternas del Consejo de Aragón, la designación recayó en otro candidato -posiblemente por la condición de oriundo de Orihuela en que incurría el pretendiente ${ }^{97}$. Y tampoco D. Andrés de Monserrate Crespí de Valldaura consiguió el ascenso en 1700, permaneciendo en su cargo de Lugarteniente en Castellón, aunque el Consejo reconocía, haciendo suyo el informe del Virrey, «haver dado muestras muy conformes a sus obligaciones en mas de trece años que se halla Governador de Castellon de la Plana». Al igual que ocurriera con D. Juan Cascante, también D. Andrés llegó a encabezar la terna en el voto particular de uno de los regentes del Consejo -el Marqués de Castelnovo-, quien estimó «seria de mucho desconsuelo deste Cavallero que V.Magd. no se sirviese de honrrarle en esta ocasión, hallándose con maior antigüedad de servicios que D. Vicente Falco»; pero finalmente se impuso la opinión mayoritaria, favorable a Falcó ${ }^{98}$.

95. ACA: CA, leg. 651, consulta del Consejo de Aragón, de 17 de diciembre de 1588; leg. 701, exp. 48/5, memorial de D. Alvaro Vique y Manrique, de 4 de octubre de 1607; leg. 868, exp. 88/2, memorial de D. Alvaro Vique y Manrique, de octubre de 1607.

96. ACA: CA, leg. 777, exp. 21/1-3, consulta del Consejo de Aragón, de 27 de mayo de 1671

97. ACA: CA, leg. 736, exp. 17/7, memorial de D. Juan Cascante García de Laza, de 1656; leg. 740, exp. 31/1-3, consulta del Consejo de Aragón, de 30 de enero de 1658; leg. 664, exp. 18, consulta del Consejo de Aragón, de 7 de febrero de 1658

98. ACA: CA, leg. 857, exp. 70/1, consulta del Consejo de Aragón, de 19 de agosto de 1700. 
A los merecimientos castrenses de D. Vicente, ya mencionados, se añadía la experiencia adquirida recientemente en la recta administración y gestión de una de las más importantes fuentes de ingresos con que contaba el Real Patrimonio en el Reino de Valencia, como eran -en expresión del Consejo- «las Rentas de Aduanas y Salinas de Alicante, cuyo manejo resolvió V.Magd encargarle mas ha de un año y en que se ha conocido un gran beneficio...por cuyas consideraciones le ha parecido inescusable el consultarle en primer lugar....a mas de estar resuelto por V.Magd vaya unida con el Gobierno» ${ }^{99}$. El servicio en la administración financiera de la Corona llegó a resultar, así, un factor determinante en la provisión de la plaza en 1700, hasta el punto de haberse decidido incorporar a las funciones tradicionales del oficio de Portantveus de Orihuela la de administrador de las rentas del derecho de Aduanas que se cobraba en el puerto alicantino y de las salinas de la Mata. Pero el origen de esta vinculación -que no alcanzó carácter orgánico, aunque sí llegó a funcionar de facto al final de la centuria- hay que situarlo unos años atrás, pues según exponía en 1696 D. Josep de Borja Llansol, en su solicitud de prórroga para otro trienio, cuando en 1693 se le nombró Portantveus de Orihuela también se le hizo merced conjuntamente de «la administración de los Reales derechos de Alicante, Salinas de la Mata y Orihuela», con el salario suplementario anexo de 500 libras anuales ${ }^{100}$. Puesto que su antecesor, D. Jaime Antonio Borrás, no llegó a disfrutar de esta situación -ni tampoco quienes le precedieron-, hay que situar en 1693 el origen de esta práctica consistente en añadir a las funciones propias del titular de la Gobernación determinadas tareas relacionadas con la gestión de algunos derechos patrimoniales de la Corona, teóricamente dependientes de la Baylía General. Tan importante como la milicia y los puestos de mando en el terreno político-jurisdiccional fue, por consiguiente, el servicio a la Corona a través de una eficaz gestión económica de sus recursos.

Además de los ya señalados, la ocupación de otros oficios en la administración real, bien de carácter político-jurisdiccional, bien de marcado perfil económico, fue mérito aducido asimismo por un buen número de candidatos a la Gobernación de Orihuela; aunque no todos podían resultar elegidos. En cambio, ser natural o avecindado en el distrito denllà Xixona no facilitaba precisamente la promoción a la titularidad del oficio, como tuvieron ocasión de comprobar, además del Lugarteniente Juan Cascante García de Lassa, otros nobles comarcanos empleados en el real servicio -al margen de las milicias-, como D. Francisco Pérez de los Cobos, y los alicantinos D. Pedro Sanz y D. Francisco Martínez de Vera.

En 1664 algunos regentes del Consejo colocaron en cabeza de la terna a Pérez de los Cobos, entre otras razones, «por el merito que ha hecho en el servicio de Su Magd en ocasión de tanta importancia como la de las revoluciones de Elche, de cuyo estado se halla oy Governador, haviendo prozedido en este cargo y en la asistencia del castillo

99. Ibidem.

100. ACA: CA, leg. 672, exp. 35/1-8, memorial de D. Josep de Borja Llansol y consulta del Consejo de Aragón, de marzo de 1696. 
de Santa Pola con toda satisfacción ${ }^{101}$. Avalaban su candidatura otros méritos propios y de sus antepasados ${ }^{102}$; pero todo ello resultó insuficiente para conseguir la plaza, «por tener la hazienda de su mujer en Orihuela, ser su ascendencia y su Padre estrangero de Valencia....y por la aplicacion a algunas negociaciones, que es de tan gran reparo en los distritos que se gobiernan» ${ }^{103}$.

Tampoco al alicantino D. Pedro Sanz le faltaban sólidos argumentos para optar al cargo en la misma vacante de 1663 -o al menos así llegó a considerarlo el interesado-, entre los cuales destacaba los servicios realizados durante dos años como Subrogado del Portantveus, otros dos como teniente del Bayle General y, de forma interina, en la administración de las salinas de la Mata, además de los protagonizados en las milicias y otros varios desempeñados por sus antecesores ${ }^{104}$. Su candidatura, sin embargo, fue completamente ignorada, no solamente por el Virrey, sino también por todos los regentes del Consejo, ya que no llegó a figurar en ninguna terna, general ni particular. Al tener que competir con pretendientes de más acrisoladas virtudes, su condición de alicantino difícilmente podía llegar a favorecerle.

Su paisano, D. Francisco Martínez de Vera, tuvo asimismo ocasión de comprobarlo unos cuantos años más tarde, cuando en 1678 figuró como candidato; esta vez, encabezando la terna del Consejo, frente a la propuesta por el Virrey. El resumen de las razones que aconsejaban su designación para el oficio hace pensar en su probable condición - pasada o presente- de Subrogado, pues en el borrador de la preceptiva consulta se valoraba expresamente «la habilidad del sujeto....pues por su mano se han pacificado los bandos mas sangrientos y numerosos que ha habido en aquellas comarcas». A tenor de una serie de consideraciones, entre las que se destacaba la holgada posición económica de D. Francisco, «que es requisito muy preciso para este empleo, pues vale muy poco y esta expuesto a muchos gastos», el Consejo le juzgaba como «el mas a propósito que en la coyuntura presente puede haber para esta ocupación..... sin que le parezca que puede obstarle el ser natural de Alicante». Sin embargo, debió ser precisamente esta última apreciación la que determinó que la designación recayera finalmente sobre el segundo de la lista: D. Juan de Cardona ${ }^{105}$.

Quedaba así de manifiesto la preferencia de la Corona por el personal foráneo, a la hora de proveer la plaza de Portantveus de Orihuela. Aunque esta circunstancia no llegó a funcionar como requisito indispensable, la práctica demuestra la conveniencia del desarraigo, como elemento a valorar en los altos oficiales jurisdiccionales de la

101. ACA: CA, leg 759, exp. 7/10, consulta del Consejo de Aragón, de 13 de mayo de 1664.

102. Ibidem, exp. 7/15-17, memoriales de D. Francisco Perez de los Cobos, de 1664 y 1663.

103. Ibídem, exp. 7/11, consulta del Consejo de Aragón, de 15 de julio de 1664.

104. Ibidem, exp. 7/16, memorial de D. Pedro Sanz, de 1663.

105. ACA: CA, leg. 797, exp. 33/1-4, borrador y consulta del Consejo de Aragón, de 8 de septiembre de 1678, y terna del Virrey, de 27 de septiembre de 1678. La referencia, en el segundo documento mencionado, a la conveniencia de «dar los motivos por que no se conforma el Consejo con la terna del Virrey» sugiere un posible error en las fechas. Como ya se ha dicho, D. Juan de Cardona se excusó y la plaza recayó en D, Francisco Guerau y Ciurana. 
Corona, para garantizar una mayor eficacia en la acción de gobierno. Para acrecentar la autoridad y la independencia de los gobernantes resultaba esencial el debilitamiento de los vínculos que pudieran atarles con los gobernados; y el mejor modo de propiciar esta situación era acudiendo a servidores alejados de intereses locales. La provisión de los oficios de Lugarteniente y de Subrogado de la Gobernación no se regía, en cambio, por estos principios, pues su concreta incardinación en el sistema administrativo exigía un perfil algo distinto; pero sí parece evidente en el caso del Portantveus, como supremo representante de la jurisdicción regia en el territorio ${ }^{106}$.

Nobles empleados en el servicio regio que aspiraron, sin éxito, a la plaza que se viene considerando fueron, asimismo, el propio asesor de la Gobernación, Dr. Hilarión Palmir, en 1663, tras serle comunicada su jubilación como jurista ${ }^{107}$; y, en 1678, el Conde de Anna y D. Luis Pallás y Vallebrera, en ambos casos con varios años de experiencia como receptores de la Baylía de Valencia ${ }^{108}$. Otros, como el Lugarteniente General de la Orden de Montesa, D. Juan Ferrer, sí llegó a obtener la plaza en 1607, inaugurando el periodo de sucesión en el mismo para dicho linaje.

Pero, más allá de los méritos contraídos en el ejercicio de oficios de la administración real, también la fidelidad a la Corona y, sobre todo, la actitud o el comportamiento personal mostrados en momentos de especial significación política, fueron elementos altamente valorados. Así ocurrió con D. Ximén Pérez Pertusa, cuya activa participación durante el movimiento agermanado en el bando realista debió tener alguna influencia en su designación posterior para ejercer la plaza de Orihuela ${ }^{109}$.

En consulta fechada el 29 de septiembre de 1656, el Consejo, siguiendo las sugerencias del Virrey, desestimó la candidatura de D. Luis Mercader para la tercera posición de la terna, e introdujo en su lugar a D. Diego Sanz de la Llosa «por ser cavallero de buenas prendas que ha servido en Cataluña y en los Estamentos y servicios que se han hecho a Su Magd. en el Reyno ha prozedido con satisfacción». Como a todo ello se añadía su condición de «hijo y nieto de ministros que también sirvieron a Su Magd. en plazas de judicatura de la real Audiencia de Valencia», D. Diego acabaría haciéndose finalmente con la titularidad de la Gobernación ${ }^{110}$. Su elección no llegaría a materializarse en este preciso momento, puesto que Felipe IV optó, inopinadamente, por un pretendiente que no figuraba en ninguna terna -D. Luis Ferrer Aragón y Apiano-; pero sí un año más tarde, cuando se produjo nueva vacante, y a pesar de que D. Diego no

106. Para el caso del Lugarteniente vid. Bernabé GIL, David: «Oficiales de la Gobernación....», Op. cit, espec. pp. $575-577$

107. ACA: CA, leg. 759, exp. 7/5, memorial del Dr. Hilario Palmir, de 1663.

108. ACA: CA, leg. 797, exp. 33/4, borrador de consulta del Consejo de Aragón, de 1678; exp. 33/2, terna del Virrey, de 27 de septiembre de 1678.

109. Refiere esa actuación, precisamente en la batalla de Orihuela, EscOLANO, Gaspar: Op, cit., pp. 693 y SS.

110. ACA: CA; leg. 736, exp. 17/19, consulta del Consejo de Aragón, de 29 de septiembre de 1656. 
llegó a pasar de la tercera posición en ninguna de las varias ternas que se confeccionaron para esta nueva ocasión ${ }^{111}$.

Conscientes del valor otorgado a una actitud contemporizadora con la Corona en sus relaciones con los estamentos, algunos candidatos no olvidaron incluir este mérito en la exposición de sus curricula. Así lo hizo D. Guillem Carroz, cuando en sendos memoriales de 1656 y de 1657 añadía a la larga lista de servicios realizados, su leal y ejemplar intervención mostrada «en las Cortes que V. Magd. fue servido celebrar en el año 1645 , procurando se efectuase el real servicio ${ }^{112}$. Perteneciente a un linaje de larga tradición en diferentes oficios de la administración regia, D. Guillem llegó a encabezar dos ternas consecutivas propuestas por el Virrey el 1 de febrero de 1656 y el 28 de octubre de 1657; pero el Consejo estimó conveniente excluirle finalmente -en consulta de 7 de febrero de 1658- al habérsele imputado un homicidio, cometido -al parecer- de forma «casual y sin premeditación alguna» ${ }^{113}$.

Menos posibilidades de resultar elegido tuvo el generoso Juan Pertusa cuando presentó por primera vez su candidatura en 1664. Pero, a la hora de exponer los méritos -seguramente escasos- que le avalaban, no podía dejar al margen sus actuaciones como síndico del estamento real. Aunque el Virrey lo colocó en tercer lugar de la terna, destacaba del pretendiente, además de haber ejercido oficios municipales en Valencia, como justicia criminal y jurado, que «en las ocasiones de estamentos siendo sindico a obrado con fineza» ${ }^{114}$. A Pertusa le tocó lidiar con candidatos de mayor enjundia, pero su posición en la terna fue mejorada por el voto particular de algunos consejeros ${ }^{115}$; y en 1671 su nombre volvió a figurar nuevamente en las propuestas al efecto ${ }^{116}$

En sentido contrario, la más mínima sospecha sobre el comportamiento perturbador del candidato en el seno del estamento militar o la evidencia de haber incurrido en notoria desafección ante las demandas regias expresadas en cortes del Reino podían resultar definitivas para su exclusión. Para la provisión del oficio en 1658 el Consejo rechazó al barón de Manises, D. Felipe Boil -hijo de quien fuera Gobernador de Valencia, D. Bernardo Boil- «aunque le propuso en las consultas antecedentes en segundo lugar, por haver reconocido después que en las relaciones que hizo el Virrey de los sujetos que procedieron con desatención en las materias del estamento militar fue uno de ellos Don Phelipe Boil $\rangle^{117}$. Contaba entonces el barón de Manises con 38 años de edad; y es posible que con el transcurso del tiempo fuera cambiando su actitud, pues en la vacante producida seis años más tarde, contó con el decidido apoyo del

111. ACA: CA; leg. 664, exp. 31/1, consulta del Consejo de Aragón, de 7 de febrero de 1658.

112. ACA: CA; leg. 736, exp. 17/7, memoriales varios de D. Guillem Carroz, de octubre de 1656; leg. 664, exp. 18/2, memorial de D. Guillem Carroz, de 1657.

113. ACA: CA; leg. 664, exp. 31/1, consulta del Consejo de Aragón, de 7 de febrero de 1658.

114. ACA: CA; leg. 759, exp. 7/10, terna del Virrey, de 13 de marzo de 1664.

115. Ibídem, exp. 7/9-10, consultas del Consejo de Aragón, de 7 de mayo y 10 de junio de 1664.

116. ACA: CA, leg. 777, exp. 21/2- 4, terna del Virrey, de 31 de marzo de 1671, y consulta del Consejo de Aragón, de 27 de mayo de 1671.

117. ACA: CA, leg. 664, exp. 31/1, consulta del Consejo de Aragón, de 7 de febrero de 1658. 
nuevo Virrey y del Monarca -además de una parte del Consejo de Aragón-, hasta el punto de resultar elegido para el cargo. Solo que, ahora, D. Felipe se excusó, alegando motivos de salud ${ }^{118}$.

Pertenecían los Boil a un linaje «de mucha sangre $\ll^{119}$ y «de los de mayor calidad de aquel Reyno» ${ }^{120}$; pero no todos sus miembros destacaron siempre como leales servidores de la Corona o de sus altos representantes, contrariamente a lo que se afirmaba en una anotación anónima -posiblemente del Vicecanciller del Consejo de Aragón- que acompañaba a una consulta de 1664. La indicación se refería ahora a la idoneidad de D. Pedro Boil, barón de Borriol, para encabezar la terna de la Gobernación oriolana, aunque venía propuesto en segundo lugar por el Virrey. En el Consejo cundía la sospecha de que tampoco este miembro del linaje aceptaría el oficio, en caso de resultar elegido; pero también había algunas reticencias en su contra por otro motivo. Según se afirmaba en otra anotación a la mencionada consulta «en algunas ocasiones del servicio de $\mathrm{V}$. Magd. que se han offrecido en aquel Reyno no ha mostrado ser sus dictamenes muy conformes a sus obligaciones y particularmente en el enquentro que tuvo el [Virrey] Marques de Camarasa el dia del Corpus del año 1661 con los jurados [de la ciudad de Valencia] sobre la forma de acompañarle, en que fomento Don Pedro las quexas de la ciudad, procurando que las asistiesen los estamentos» ${ }^{121}$. Para la mayor parte de los consejeros, sin embargo, la posición del barón de Borriol durante el altercado no constituía indicio suficiente de desafección, pues «en una o otra ocasión puede errar el entendimiento»; por consiguiente «el decir que es enemigo del servicio de V.Mgd. es de gran reparo en hombre que tiene de las primeras calidades del Reyno, que toda su casa ha dado tantas muestras de su lealtad» ${ }^{122}$. Ante esta división de criterios, Felipe IV decidió aplazar la provisión del oficio hasta conocer el informe escrito del anterior Virrey, el Marqués de Camarasa, «acerca del proceder de Don Pedro Boil en las materias del servicio de Su Magd.» ${ }^{123}$. Y, a juzgar por la resolución final del caso, el relato de Camarasa debió resultar determinante, pues la designación recayó finalmente en el Marqués de la Casta, cuya candidatura había contado con el apoyo decisivo del actual Virrey, el Marqués de San Román ${ }^{124}$.

La exclusión de D. Pedro mostraba la importancia de la fidelidad inquebrantable como elemento a valorar por la Corona a la hora de decidir en quien depositar su confianza para desarrollar con garantías las funciones gubernativas. Pero, al igual que había ocurrido con el barón de Manises, el de Borriol también habría de tener tiempo y ocasión para disipar cualquier duda sobre su leal posición y mostrar la improceden-

118. ACA: CA, leg. 759, exp. 7/10-11, terna del Virrey, de 13 de marzo de 1664; consulta del Consejo de Aragón, de 15 de julio de 1664 .

119. ACA: CA, leg. 736, 17/2, consulta del Consejo de Aragón, de 29 de julio de 1656.

120. ACA: CA, Leg 664, 31/1, consulta del Consejo de Aragón, de 7 de febrero de 1658.

121. ACA: CA, Leg 759, 7/12, anexo a consulta del Consejo de Aragón, de 15 de julio de 1664.

122. ACA: CA, leg. 759, 7/13, anexo a consulta del Consejo de Aragón, de 15 de julio de 1664.

123. ACA: CA, leg. 759, 7/14, respuestas a la consulta del Consejo de Aragón, de 18 y 24 de julio de 1664. 124. ACA: CA, leg. 759, 7/11, consulta del Consejo de Aragón, de 15 de julio de 1664. 
cia de esas sospechas que, de algún modo, podían contribuir a manchar una tradición familiar de servicio. Para recoger los frutos de esa actitud aun tendría que esperar, sin embargo, algún tiempo; concretamente, hasta la vacante producida en 1675 nuevamente en la Gobernación de Orihuela. Fue entonces cuando, al encabezar la terna virreinal «por su gran calidad y canas, virtud y entereza, y todas buenas partes y por lo que el y todos los suios han servido a V.Mgd.», el Consejo no tuvo inconveniente en respaldar la candidatura de D. Pedro; ni él, en aceptar su nombramiento ${ }^{125}$.

El servicio a la Corona, realizado con una lealtad sin fisuras a través de las múltiples facetas en que podía expresarse aquella voluntad, bien en el ejército, bien en el desempeño de cargos, pero también en actitudes y comportamientos solidarios con sus aspiraciones políticas, operaba como un activo que sobrepasaba el ámbito de lo individual, para convertirse en una especie de patrimonio familiar. Tan importante como el mérito personal podía llegar a ser, si aun no se había tenido oportunidad de cultivarlo con la suficiente amplitud o intensidad, el que se había ido acumulando, generación tras generación, en un mismo linaje. Los servicios de los antepasados cobraban así una dimensión casi equiparable a los propios, al tiempo que éstos mismos podían ser aprovechados por generaciones futuras; e incluso los realizados por todo tipo de familiares.

Aunque para el siglo XVI no disponemos de memoriales de pretendientes, la proximidad del padre y del hermano de D. Juan Quintana -D. Pedro, en ambos casosa las reales personas de Carlos V y de Felipe II no debió ser ajena a su nombramiento para la plaza de Orihuela en $1581^{126}$. Como tampoco podía pasar desapercibida la larga tradición de los Vique en el real servicio, a través de la ocupación de la Baylía General de Orihuela desde mediados del siglo XVI -por ejemplo-, para sustentar la gracia otorgada a D. Alvaro en 1588.

En 1606, el pretendiente D. Luis Blasco completó su hoja de servicios personales con referencias a destacados antepasados que mostraron su lealtad en «cosas memorables contra los comuneros», a un tío que fue Dean en Valencia e Inquisidor en Barcelona y a un hermano que murió en el asalto de Ostende ${ }^{127}$. Medio siglo más tarde D. Guillem Carroz tampoco olvidó mencionar «los servicios continuados de Padre, tio y Aguelos assi en el officio de Bayle General como en otros de que consta a V. Magd.» ${ }^{128}$. Y, este mismo año, D. Diego Sanz de la Llosa detallaba los cargos ocupados por su abuelo D. Ramón -«34 años continuos en los oficios de Assesor del Bayle General, Abogado Patrimonial del Consejo Criminal y del Civil y los 20 y mas de Lugarteniente de Thesorero General de V.Magd. en aquel Reyno»-y por su padre D. Baltasar-además de 26 años en los dos primeros oficios anteriores, «de Assesor de la

125. ACA: CA, leg. 787, 99, terna del Virrey, de 27 de agosto de 1675; y consulta del Consejo de Aragón, de 4 de noviembre de 1675.

126. ESCOLANO, Gaspar: Op. cit., pp. 522-524.

127. ACA: CA, leg. 866, exp. 28/1, memorial de D. Luis Blasco, de 30 de agosto de 1606.

128. ACA: CA, leg. 736, exp. 17/8, memorial de D. Guillem Carroz, de 1656. 
Orden de Montessa» ${ }^{129}$. D. Pedro Giner, por su parte, avalaba su candidatura, no solo con el relato de sus propias hazañas militares realizadas en diferentes frentes, sino también con una referencia a las de su padre, que «sirvió a V. Magd. en la guerra mas de 40 años continuos y murió siendo Governador y Capitan a guerra de la Ciudad y presidio de Gaeta» ${ }^{130}$.

También en 1663 fueron varios los pretendientes que sacaron a relucir sus glorias familiares con la esperanza de afianzar por este medio sus candidaturas. D. Pedro Sanz se remontaba hasta su bisabuelo, D. Gaspar, cuyos servicios al emperador Carlos V como capitán de caballos de la costa del Reino se extendió a lo largo de 36 años, en los que empeñó su hacienda para pagar a los soldados a su cargo y protagonizó diferentes episodios relacionados con el control de los moriscos y el rechazo de los berberiscos, pues «benian muy de ordinario los de Argel y otras partes a tratar con ellos...y cautivo a muchos, asi de los de Argel como del mismo Reino de los nuevamente convertidos que intentaban embarcarse». Pero también su padre, de nombre igualmente Gaspar, fue empleado en el real servicio, «de subrrogado de Governador en diferentes ocasiones, catorce años de la ciudad y Reino de Valencia, y en la ciudad de Orihuela 2 años mientras estuvo suspendido el Conde de Almenara, y en la Orden de Montesa de sotsclavero de la misma Orden en interin...y en propiedad 3 años, hasta que murió en el castillo de Montesa». E incluso su hermano D. Francisco, también capitán de caballos, murió peleando en la defensa de Cataluña frente a los franceses ${ }^{131}$. De mayor antigüedad, pues se remontaba a ocho generaciones atrás -allá por el año de 1413-, era el origen de los servicios que venían vinculando ininterrumpidamente a los Pérez de los Cobos con la monarquía, en este caso castellana. A todos ellos y a los de los antepasados de su esposa, $D^{a}$ Concordia Dominguez y Zanoguera - vinculados a la Baylía-, se refería expresamente D. Francisco Pérez en un extenso memorial que dio a la imprenta en 1663 para conseguir la Gobernación oriolana; con el infructuoso resultado que ya conoce$\operatorname{mos}^{132}$. La concepción de los servicios acumulados por los antecesores como un patrimonio familiar quedó claramente expresada, en fin, por D. Jerónimo Vallterra Blanes y Brisuela cuando, en 1700, glosaba los realizados por su padre, para acabar «dexando al suplicante heredero de sus servicios y deseando continuar los heredados»» ${ }^{133}$.

La mención de los servicios protagonizados por los ascendientes, aunque formaba parte del discurso habitual de los pretendientes a la gracia regia y de quienes elaboraban las ternas, tampoco obraron efectos decisivos en los casos de D. Josep Blanes, en 1671; de D. Francisco Villacampa, en 1675; y de D. Andrés de Monserrate Crespí de Valldaura, en 1692 y, nuevamente, en 1700. Estas tres candidaturas figuraron en las respectivas ternas virreinales para cubrir las vacantes de esos años, pero en ningún

129. ACA: CA, leg. 736, exp. 17/16, memorial de D. Diego Sanz de la Llosa, de 1656.

130. ACA: CA, leg. 736, exp. 17/88, memorial de D. Pedro Xiner, de 1656

131. ACA: CA, leg. 759, exp. 7/16, memorial de D. Pedro Sanz, de 1663.

132. ACA: CA, leg. 759, exp. 7/17, memorial de D. Francisco Pérez de los Cobos, de 1663.

133. ACA: CA, leg. 857, exp. 70/3, Memorial de D. Jerónimo Vallterra Blanes y Brisuela, de 1700. 
caso para encabezarlas, y sin que pueda asegurarse que existieran memoriales de los interesados con las correspondientes alegaciones de méritos ${ }^{134}$. Los dos últimos eran descendientes directos de regentes del Consejo de Aragón, mientras que Blanes era hijo del Lugarteniente del Tesorero General; pero por diversas circunstancias no obtuvieron la Gobernación oriolana, debiéndose conformar quizás alguno de ellos con otros empleos en el real servicio.

Independientemente de que llegara a resultar finalmente uno de los elementos determinantes en la elección, la continua referencia a estos antecedentes familiares por parte de los pretendientes pone de manifiesto la importancia que se otorgaba a la sangre como vía de transmisión y conservación de los méritos contraídos por el linaje. La vinculación familiar con otros oficiales regios que habían servido de forma satisfactoria constituía, además, un aval de fidelidad e incluso de cierta capacidad para el desempeño del cargo, que incrementaba las posibilidades de resultar elegido.

El discurso enaltecedor del parentesco, que legitimaba y favorecía la formación de amplias redes familiares y clientelares en la administración regia -y no sólo en ella-, tenía, sin embargo, su necesario contrapunto en la doctrina defensora de la ecuanimidad, contraria al nepotismo. En aplicación de este principio, los miembros del Consejo no podían votar las ternas en que figurase algún pariente propio hasta el cuarto grado, sino que -como se ha dicho más arriba- debían presentar su propia terna y abandonar momentáneamente el recinto donde se iba a proceder a la votación general. Esta situación ha podido ser documentada en nueve ocasiones -distribuidas en cinco años: $1656,1657,1664,1671$ y $1678-\mathrm{y}$, sobre todo cuando afectaba a más de un consejero, propiciaba la formación de muchas ternas, pues cada propuesta particular solía ampliar el número de candidatos ${ }^{135}$. Los nuevos nombres introducidos por los votos particulares, además, podían inducir a la realización de sucesivas votaciones en las que, a su vez, podían excluirse consejeros con relación de parentesco. El procedimiento seguido posibilitaba, por tanto, que cualquier consejero, aunque estuviera impedido para la votación general, forzase la exclusión de otros colegas mediante la táctica de incluir en su terna particular candidatos con relaciones de parentesco entre aquéllos. En definitiva, el juego de las componendas no impedía que pudiera encabezar la terna un candidato con relaciones familiares en el Consejo. Pero esta circunstancia solo se produjo, de los cuatro años mencionados, en 1664, cuando resultó elegido el Marqués de la Casta, pariente del consejero de capa y espada, el Conde de Albatera. Por lo demás, el número de candidatos que optaron al oficio con las miras puestas en el posible apoyo que pudieran obtener de un consejero familiar -incluidos los que concurrieron involuntariamente o sin haber manifestado expresamente su intención de

134. ACA: CA, leg. 777, exp. 21/4, terna del Virrey, de 31 de marzo de 1671; leg. 787, exp. 99, terna del Virrey, de 27 de agosto de 1675; leg. 857, terna del Virrey y consulta del Consejo de Aragón, de agosto de 1700 .

135. ACA: CA, leg. 736, exp. 17; leg. 664, exp. 31/1-2; leg. 740, exp. 31/1-3; leg. 759, exp. 7/7-11; leg. 777, exp. 21/2; leg. 797 , exp. 33/1. 
hacerlo- alcanzó la cifra de nueve, para un total de 52; lo que representa una escasa proporción del $18 \%{ }^{136}$.

Finalmente, entre los méritos destacables de los candidatos también solía hacerse expresa alusión, por parte de quienes tenían que valorar sus aptitudes, a una serie de cualidades y virtudes que adornaban su personalidad. Las referencias a estas capacidades individuales podían ensalzar aspectos peculiares del carácter psicológico de los candidatos; pero lo más habitual consistía en recurrir a una serie de epítetos, en su mayor parte perfectamente codificados $-\mathrm{y}$, por tal motivo, un tanto manidos por el uso reiterado-, para dar cuenta de su idoneidad. El «buen juicio», la «prudencia», la «mucha calidad», el «buen celo», las «buenas prendas», la «experiencia», la «capacidad», las «buenas partes», las «canas», la «entereza», el «talento», la «aplicación», la «buena conducta», eran virtudes que, agrupadas en combinaciones de varios elementos, aparecen con frecuencia en las valoraciones justificativas de las ternas propuestas.

En la designación para ejercer el oficio intervenía, por consiguiente, una serie de elementos que, en general, era suficientemente conocida, tanto por los potenciales aspirantes como por los sectores de la administración implicados en el proceso selectivo. Y en ese conglomerado de variables a considerar, era el diverso peso específico de cada una, de incierta ponderación, lo que facilitaba la concurrencia de candidatos. La naturaleza aparentemente discrecional pero sólo hasta cierto punto impredecible de la decisión final -reservada al Monarca- no impedía, sin embargo, que, de forma tácita, el lenguaje y los elementos discursivos manejados por unos y otros se orientaran no solamente a la conformación de una determinada concepción sobre el sentido profundo de esta específica modalidad de administración de la gracia, sino también al establecimiento de una cierta jerarquía entre los condicionantes por los que ésta había de regirse. El lugar que ocupaba en esa implícita ordenación interna cada uno de los méritos esgrimidos podía traducir una gradación de los criterios operativos en cada coyuntura o etapa histórica y, de ese modo, reflejar aspectos relevantes del sistema de valores vigente; pero no alcanzó el grado de rigidez necesario para hacer de la designación final un acto de significado perfectamente previsible. Tan importante como conocer la personalidad de los agraciados en los nombramientos es, por tanto, atender a los procesos previos para tratar de reconstruir, en la medida de lo posible, los caminos que condujeron hasta aquellas decisiones; y, de ese modo, encontrarles un sentido.

136. Mantenían relaciones de parentesco con algún miembro del Consejo de Aragón los siguientes candidatos: D. Juan de Castellví, con el Vicecanciller, en 1656; D. Guillém y D. Antonio Carroz, con el Conde de Albatera, en 1656 y en 1657; D. Pedro Sanz, con el regente D. Antonio Ferrer, en 1664; el Marqués de la Casta, con el Conde de Albatera, en 1664; D. Felipe Boil, con el Vicecanciller, en 1664; Juan Pertusa, con el regente D. Antonio Ferrer, en 1671; D. Josep de Blanes, con el Vicecanciller, en 1671; el Conde de Anna, con el regente D. Antonio de Calatayud, en 1678. Referencias documentales en nota anterior. 
Tabla 1

Titulares del oficio de Portantveus de Gobernador General de Orihuela

\begin{tabular}{|l|c|}
\hline \multicolumn{1}{|c|}{ Titular } & Años \\
\hline D. Pedro Maza de Lizana y Carroz & $1521-1546$ \\
D. Ximen Pérez Pertusa & $1546-1548$ \\
D. Guillem de Rocafull & $1548-1553$ \\
D. Nuño del Aguila & 1553 \\
D. Juan de Moncayo & $1553-1566$ \\
D. Enrique de Palafox & $1566-1581$ \\
D. Juan Quintana & $1581-1586$ \\
D. Ximen Pérez Calatayud & $1586-1588$ \\
D. Alvaro Vique y Manrique & $1588-1607$ \\
D. Juan Ferrer y Calatayud & $1607-1626$ \\
D. Luis Ferrer y Proxita & $1626-1645$ \\
D. Gerardo Ferrer y Proxita & $1645-1656$ \\
D. Luis Ferrer Aragón y Apiano & $1656-1657$ \\
D. Diego Sanz de la Llosa & $1658-1664$ \\
El Marqués de la Casta & $1664-1671$ \\
D. Francisco de Calatayud & $1671-1673$ \\
D. Miguel de Fenollet & $1673-1675$ \\
D. Pedro Boil y Borriol & $1675-1678$ \\
D. Francisco Guerau Ciurana & $1679-1685$ \\
D. Juan de Cardona & $1685-1686$ \\
D. Jaime Antonio Borrás & $1686-1692$ \\
D. José de Borja Llansol & $1693-1700$ \\
D. Vicente Falcó y Blanes & $1700-1706$ \\
\hline
\end{tabular}

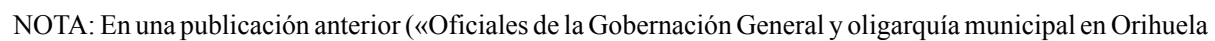
durante el siglo XVII», en FERNÁNDEZ ALBALADEJO, Pablo (ed.): Monarquía, Imperio y Pueblos en la España Moderna, C.A.M.-Universidad de Alicante, A.E.H.M., Alicante, 1997, p. 580) incluí ya un listado de Gobernadores como «ANEXO I. TITULARES DEL OFICIO DE PORTANTVEUS DE GOBERNADOR GENERAL DE ORIHUELA (datos provisionales)», en el que señalaba «el carácter de provisionalidad» que afectaba a un buen número de datos cronológicos, expresamente marcados con signos de interrogación. La TABLA que ahora se ofrece invalida, por tanto, aquella otra, a la que sustituye de manera definitiva. 
Tabla 2

Candidatos al oficio de Portantveus de Gobernador de Orihuela (a partir de 1588)

\begin{tabular}{|c|c|c|}
\hline Año & Candidatos & Observaciones \\
\hline \multirow[t]{2}{*}{1588} & D. Alonso Zanoguera & Elegido y renuncia \\
\hline & D. Alvaro Vique y Manrique & Elegido \\
\hline \multirow[t]{7}{*}{1606} & D. Juan Ferrer y Calatayud & Elegido \\
\hline & D. Francisco Crespí de Valldaura & \\
\hline & D. Luis Blasco & \\
\hline & D. Francisco Milán de Aragón & \\
\hline & D. Baltasar Ladrón & \\
\hline & D. Francisco de Borja & \\
\hline & D. Felipe Borriol & \\
\hline \multirow[t]{11}{*}{1656} & D. Luis Ferrer Aragón de Apiano & $\begin{array}{l}\text { Elegido y promocionado al año } \\
\text { siguiente }\end{array}$ \\
\hline & D. Guillem Carroz & \\
\hline & D. Juan de Castellví Villanova & \\
\hline & D. Antonio Carroz & \\
\hline & Juan Cascant García de Lasa & \\
\hline & D. Felipe Boil & \\
\hline & D. Luis Mercader & \\
\hline & D. Diego Sanz de la LLosa & \\
\hline & D. Pedro Giner & \\
\hline & D. Gaspar de Proxita & \\
\hline & D. Enrique Escorcia y Ladrón & \\
\hline \multirow[t]{9}{*}{$1657 / 8$} & D. Diego Sanz de la Llosa & $\begin{array}{c}\text { Elegido } \\
\text { Candidato el año anterior }\end{array}$ \\
\hline & D. Guillem Carroz & Candidato el año anterior \\
\hline & Juan Cascant García de Lasa & Candidato el año anterior \\
\hline & D. Felipe Boil & Candidato el año anterior \\
\hline & D. Luis Mercader & Candidato el año anterior \\
\hline & D. Juan de Castellvi Villanova & Candidato el año anterior \\
\hline & D. Pedro Boil de Arenós & \\
\hline & D. Luis Maza de Lizana & \\
\hline & Juan Pertusa & \\
\hline 1661 & D. Diego Sanz de la Llosa & Reelegido \\
\hline \multirow[t]{7}{*}{1664} & D. Felipe Boil & $\begin{array}{c}\text { Elegido y renuncia } \\
\text { Candidato en } 1656 \text { y } 1657\end{array}$ \\
\hline & EI Marqués de la Casta & Elegido \\
\hline & D. Pedro Boil de Arenós & Candidato en 1657 \\
\hline & Juan Pertusa & Candidato en 1657 \\
\hline & D. Francisco Pérez de los Cobos & \\
\hline & D. Francisco Ferrer Calatayud & \\
\hline & D. José de Calatayud y Pallás & \\
\hline
\end{tabular}




\begin{tabular}{|c|c|c|}
\hline & D. Pedro Sanz & \\
\hline & D. Francisco Artes y Muñoz & \\
\hline & D. Francisco Despuig & \\
\hline & Dr. Hilarión Palmir & \\
\hline & D. Luis Pallás & \\
\hline 1667 & El Marqués de la Casta & Reelegido \\
\hline \multirow[t]{4}{*}{1671} & D. Francisco de Calatayud y Villarrasa & Elegido \\
\hline & D. Juan Pertusa & Candidato en 1657 y 1664 \\
\hline & D. Josep de Blanes & \\
\hline & D. Josep de Borja y Llansol & \\
\hline \multirow[t]{4}{*}{1673} & D. Francisco Valls y Castellví & Elegido y renuncia \\
\hline & D. Miguel Fenollet & Elegido \\
\hline & D. Antonio Carroz & \\
\hline & D. Vicente Figuerola & \\
\hline \multirow[t]{3}{*}{1675} & D. Pedro de Boil y Arenós & $\begin{array}{c}\text { Elegido } \\
\text { Candidato en } 1657\end{array}$ \\
\hline & El Conde de Ana & \\
\hline & D. Francisco de Villacampa & \\
\hline \multirow[t]{8}{*}{1678} & D. Juan de Cardona & Elegido y renuncia \\
\hline & D. Francisco Guerau y Ciurana & Elegido \\
\hline & D. Luis Pallás y Vallebrera & Candidato en 1664 \\
\hline & D. Francisco Artes y Muñoz & Candidato en 1664 \\
\hline & D. Vicente Figuerola y Vives & Candidato en 1673 \\
\hline & El Conde de Ana & Candidato en 1675 \\
\hline & D. Jaime Borrás & \\
\hline & D. Francisco Martínez de Vera & \\
\hline \multirow[t]{3}{*}{1682} & D. Francisco Guerau y Ciurana & Reelegido \\
\hline & El Conde de Casal & \\
\hline & D. Antonio Boil & \\
\hline 1686 & D. Jaime Antonio Borrás & $\begin{array}{c}\text { Elegido } \\
\text { Candidato en } 1678\end{array}$ \\
\hline \multirow[t]{2}{*}{1689} & D. Jaime Antonio Borrás & Reelegido \\
\hline & D. Ventura Ferrer & \\
\hline \multirow[t]{3}{*}{1693} & D. Josep de Borja y Llansol & $\begin{array}{c}\text { Elegido } \\
\text { Candidato en } 1671\end{array}$ \\
\hline & D. Vicente Falcó y Blanes & \\
\hline & D. Andrés Monserrate & \\
\hline 1697 & D. Josep de Borja y Llansol & Reelegido \\
\hline \multirow[t]{4}{*}{1700} & D. Vicente Falcó y Blanes & Candidato en 1693 \\
\hline & D. Andrés Monserrate Crespí de Valldaura & Candidato en 1693 \\
\hline & D. Sebastián Pertusa & \\
\hline & D. Jerónimo Vallterra Blanes y Bizuela & \\
\hline
\end{tabular}

Nombres en negrita: candidatos que resultaron elegidos

Nombres en cursiva: candidatos que ya lo habían sido anteriormente en alguna ocasión 


\section{APENDICE DOCUMENTAL}

\section{Documento 1: Memorial de D. Diego Sanz de la Llosa pidiendo la plaza de Gobernador de Orihuela (1660)}

Señor: Don Diego Sanz de la Llosa digo, que mi Abuelo don Ramon Sanz de la Llosa sirvió a V. Magd. en los ofisios de Asesor de Bayle General de la Ciudad y Reyno de Valensia, y en el Consejo Criminal y Sivil de dicho Reyno por espasio de treinta y un años, y en este tiempo sirvió la Lugartenencia de Tesorero General de dicha Ciudad y Reyno diez y siete años con toda satisfacion de V. Magd y sus Ministros, dando muy buena cuenta de las grandes sumas de dinero que entraron en su poder. Y asi mesmo mi Padre don Balthasar Sanz de la Llosa sirvió a V. Magd. en los ofisios de Asesor de Bayle General Avogado Patrimonial y del Consejo Sivil de Valencia veintisinco años, y en ellos sirvió doce la Asesoria de Montesa con la satisfasion que saben los Ministros Provinsiales deste Consejo. Tambien se empleo en servir a V. Magd sin sueldo alguno en proveer los exercitos de V. Magd. en Perpiñan, Roses, Colibre y Tarragona de todos los viveres y pertrechos de guerra que se inbiaron a dichas Plaças, y los viveres que remitió y hiço fabricar fueron tantos que el cargo que se le hiço en el ofisio de Maestre Rasional en una definision sola de sus cuentas sin las otras que dio allí ni las cuentas que dio a la veheduria de don Juan de Benavides del trigo solo que hiço fabricar biscocho que fue casi todo y arina importa ocho mil ciento y diez y siete caices, como consta por la difinision de una cuenta que presenta para que en ella se vea un borron de sus trabajos y benefisio con el y su industria en cantidades considerables el Patrimonio Real de V. Magd. y fue tanto lo que trabajo en esto pasando noches enteras en el invierno a la lengua del agua por aviar los navios con brevedad sin reparar en sus muchos años, que rindió la vida a los afanes insoportables que cargaron sobre sus ombros. Y yo Señor procurando seguir las pisadas de mi Padre y Abuelo servi a V. Magd. embarcándome en la Capitana de España que governava el Duque de Maqueda donde pelehe con el enemigo quando le hechamos de la Playa de Tarragona quando la tenia sitiada el Arçobispo de Burdeus, y también quando el enemigo sitio a Tortosa sali a mi costa a servir a V. Magd. acompañando al Conde de Oropesa, asi en esta facsion como en la persecusion de los Bandidos del Reyno de Valensia, de todo lo qual presento las fehes necesarias, y asi atento a todos estos considerables servicios, y que de ninguno tengo yo ni tuvo mi Pdre merced efectiva ninguna, Suplico a V. Magd. sea servido de onrrarme con el ofisio de Governador de Orihuela y Alicante para que logre la dicha de continuar los servicios de mis pasados lo qual confio de su clemensia de V. Magd.

(ACA: CA, Leg. 664, exp. 18/3) 


\section{Documento 2: Memorial de D. Pedro Sanz solicitando la plaza de Gobernador de Orihuela (1663)}

Señor: Don Pedro Sanz, Dice que D. Gaspar Sanz su bisaguelo sirvio a la C.O. $\mathrm{Mg}$. del señor emperador Carlos quinto de Capitan de Cavallos en la costa del Reino de Valencia por tiempo de 36 años con excesivo travaxo por no aver entonces en aquella costa otra compañía y porque a ocasion de los moriscos que avitavan aquel Reino benian muy de ordinario los de Argel y otras partes a tratar con ellos con los quales tubo diferentes reencuentros y cautibo a muchos assi de los de Argel como del mismo Reino de los nuevamente conbertidos que intentavan embarcarse. Y porque el sueldo era muy corto y no se pagaba a los soldados empeño su Hacienda para socorrerles porque la compañía no se deshiciese y por esto y por lo que se devia de su sueldo con esto se le devia 3.950 libras y sueldos las quales se mandaron pagar por sentencia publicada en 16 de Mayo 1546 las quales no pudo cobrar por entero por no haver entonces bastante dinero en la Receta General de aquel Reino con que se le quedan deviendo al suplicante que a sucedido en estos derechos cerca de 2.000 libras. Asimismo sirvio el Padre del supplicante Don Gaspar Sanz de subrrogado de governador en diferentes ocasiones catorce años de la ciudad y Reino de Valencia y en la ciudad de Orihuela 2 años mientras estubo suspendido el Conde de Almenar, y en la orden de Montessa de sotsclavero de la misma orden en ynterim antes que lo sirviese Don Bernave Ballterra, y despues de este lo sirvio en propiedad 3 años hasta que murio en el castillo de Montessa. Y Don Francisco Sanz mi Hermano Cavallero del avito de la misma Orden sirvio ansimismo a V.M. de Cappitan de cavallos de la compañía de su orden en el principado de Cataluña a donde murio peleando con el valor que es notorio los reencuentros que la cavalleria que estava a cargo de Don Pedro de Aragon tubo con la que governava Monsiur de la Mota y ultimamente a servido el supplicante a S.M. de subrogado de Governador en la Ciudad de Orihuela cerca de dos años, y en este tiempo desarmo los franceses y hiço la leva de uno por ciento persiguio los vandidos que inquietavan aquella Governacion y en los que pretendio executar castigos exemplares obrando por si mismo en la leva y desarmar los franceses discurriendo por todo el distrito de la Governacion con gasto considerable sin haver tenido satisfacion alguna sirvio tambien dos años de subrrogado de Bayle general en la ciudad de Alicante y en la misma siendo Jurado primero por los cavalleros el año 1656 facilito el alojamiento de la Cavalleria en aquel Reino procuro y esforço entonces y todas ocasiones los servicios que se an hecho a V.M. para las Guerras de Cataluña y otras partes, tambien sirvio en interim el oficio de administrador de las Salinas de la Mata asta que V.M. las arrendo haviendo sido considerable la mejora que tubieron mientras duro el ynterim. Por todo lo qual y porque desea el suplicante continuar el servir a V.M. supplica Umillmente sea V.M. servido hacerle merced de darle la Governacion de Orihuela en cumpliendo el tiempo que le falta para su trienio a Don Diego Sanz de la LLossa, que en ello la recivira el suplicante muy particular de la Real mano de V.M.

(ACA: CA, Leg. 759, exp. 7/16) 


\section{Documento 3: Memorial de D. Josep de Borja Llansol solicitando la plaza de Gobernador de Orihuela (1671)}

Señora: El Maese de Campo Don Josep de Borja Lançol Cavallero del abito de Montesa y Baylio de Sueca por su Religion: Dice que sirvió a Su Magd. (que Santa gloria haya) de paje de Guion nueve años; cinco de Capitan de Cavallos Corazas en el Estado de Milan y quatro de reformado en Estremadura, de donde fue a gobernar la Isla de Menorca, con titulo de Portant-vezes de Virrey y Cappitan General, portándose con la aprobación que le mereció que V. Magd. le honrrase con un tercio de Infantería Española, que ocupo tres años en la Armada Real del Mar Oceano; habiendo sido consultado en los gobiernos de su graduación, y en el de Iviza dos vezes, como por el Consejo de Guerra quatro años ha para General de la Artilleria.

Suplica a Su Magd. (postrado a sus Reales pies) que en consideración de dichos servicios y consultas le mande honrrar ocupándole en el Gobierno de Alicante, que recibirá particular merced de V. Magd.

(ACA: CA, Leg. 777, exp. 21)

\section{Documento 4: Memorial de D. Jerónimo Vallterra Blanes y Brisuela solicitando la plaza de Gobernador de Orihuela (1700)}

Señor: Dn Geronimo Vallterra Blanes y Brisuela Cavallero de la Orden de Nuestra Señora de Montesa: dize que sus ascendientes siendo de los conquistadores del Reyno de Valencia desde su expugnacion sirviendo al invictisimo señor Rey D. Jayme se han ocupado incesantemente en el Real servicio en todas ocasiones de Guerra y Paz en cuya continuacion D. Vicente Vallterra Aguelo del supplicante sirvio el officio de Teniente de Portantvezes de General Governador de aquella ciudad y Reyno, haviendo durante su vida executado diferentes commisiones de los Virreyes en el Real servicio con el merito de la aprobacion. Assimismo D. Carlos Vallterra y Blanes Padre del suplicante haviendo servido a V. M. de Assesor de la Governacion, despues de Juez civil passo a la Plaza de Regente de aquella Audiencia en cuyo empleo murio, siendo infinitas las ocasiones que logro en el Real servicio en negocios de la mayor importancia, dexando al suplicante heredero de sus servicios y deseando continuar los heredados.

Supplica a V.M. se sirva honrrar al suplicante haziendole merecedor del oficio de Portantveus de Governador de la Ciudad de Origuela que vaca por muerte de D. Josep de Borja y Lanzol en que recibira especial gracia de V.M.

(ACA: CA, Leg. 857, exp. 70/3)

Documentos 5 y 6: Dos Memoriales del Gobernador de Orihuela, D. Alvaro Vique y Manrique, solicitando la jubilación y varias mercedes (1607)

\section{I}

Señor. Aviendo suplicado a V. Magd. Fuese de su real servicio hacerme merzed atento a mi vejez y poca salud de darme gobierno para dexar mi cargo de governador de origuela no fue servido V. Magd. dello mandándome proseguir mis servicios en 
dicho cargo obedesi a V. Magd. Y e servido en el después aca tres años con los quales ha veinte que sirvo dicho oficio y en el de governador de Xativa servi otros tres y cinco de paje de Su Magd. questa en el cielo y diez y seys le servi de soldado alférez y capitan hallándome en las jornadas que en mis papeles an visto los del Consejo de V. Magd. Y en los dichos tres años últimos que he servido en mi gobierno prendiendo y justiciando muchos delinquentes he hecho muy gran servicio a dios y a V. Magd. asegurando aquella parte de Reyno que llego a estar muy perdida y en esto he acabado de consumir la poca hacienda que me quedaba de mi patrimonio y e perdido mi salud de suerte que no puedo acudir a las obligaciones de mi cargo y mas con los trabajos que me an sobrevenido por la muerte de don Pedro mi ermano cuyo sucesor soy y asi ternia cargada mi conciencia si por mi ubiese falta en aquel gobierno atento a esto suplico a V. Magd. con la umilda que puedo sea del real servicio de V. Magd. hazerme merze de darme su grata licencia para dexar mi cargo y en consideracion de mis servicios aquí referidos a V. Magd. de quarenta y quatro años los quales suceden a todos los de mis antecesores y también que dexo ya a don diego mi hijo mayorazgo en servicio de V. Magd. en Napoles que seguira mis pasos y los de sus pasados suplico a V. Magd. atento a todo lo dicho me haga las merzedes que en mis memoriales pido a V. Magd. mostrando publica satisfacion de mis servicios para que yo me retire a mi casa con la reputación y galardón que merezen los gastos y trabajos que fuera della he sustentado sirviendo a V. Magd. y si no he servido conforme lo he deseado y procurado suplico umilmente a V. Magd. supla lo quen esto puedo haver faltado la real clemencia y grandeza de V. Magd. pues he servido con celo de onrrado caballero. Guarde nuestro Señor la Real y católica persona de V. Magd. como la christiandad a menester. De Valencia a 4 de otubre año 1607. Don Alvaro Vique y Manrrique (rubrica).

(ACA: CA, Leg. 701, exp. 48/1)

\section{II}

Señor: Don Alvaro Vique dice que ha servido a V. Magd. quarenta y quatro años los cinco de paje a la Catholica del Rey Don Phelippe que esta en el cielo padre de V. Magd. y dos diez y seis de soldado Alferez y Capitan, hallandosse en jornadas y occassiones ymportantissimas como se veen por los papeles que de ellas ha mostrado y tres años de Governador de Jatiba y veinte de Origuela que ahora exerce, y en todos con la satisfacion que ha sido notoria los quales dichos servicios por haverlos hecho fuera de su casa le han sido de grandissima costa y quiebra de salud, por lo que se teme de no poder acudir como hasta aquí a las obligaciones de su officio y al presente que por fallecimiento de Don Pedro Vique su hermano le vino el mayorazgo de su casa con lo qual se le han recrescido tantos pleitos que si no es cargando su conciencia no los puede dejar de defender por ser sobre hacienda de sus hijos. Por todo lo qual supplica a V. Magd. muy humilmente sea de su Real servicio mandarle dar grata licencia para dejar el dicho cargo de gobernador de Origuela, y que en recompensa del y galardón de dichos servicios se le haga merced del officio de Credenciero de la dicha Ciudad de Origuela para si y sus descendientes, que le pueda servir por substituto que sea de 
confianza, el qual dicho officio vale ducientos y veinte ducados pocos mas o menos y vaca por muerte de Gaspar Remiro de Espejo.

Ansi mesmo el dicho Don Alvaro Vique ha que tiene el havito de Santiago treinta y un años, y diez y seis la encomienda de Fradel, que vale quatro mil Reales Supplica a V. Magd, se sirva de mejorarsela y hacerle merced de alguna pension sobre el obispado de Mallorca para Don Alvaro Vique su hijo, con que pueda proseguir sus estudios, y en el interim que V. Magd. es servido de mandarlo hacer esta merce se le pague en su casa el sueldo de su cargo, que es seiscientos escudos como se ha hecho con otros mostrando con esto la satisfacion de sus servicios y poder retirarse con la reputación y nombre de perpetuo criado de V. Magd.

(ACA: CA, Leg. 866, Exp. 88/2)

\section{Documento 7: Consulta del Consejo de Aragón sobre petición del Gobernador de Orihuela D. Juan Ferrer en favor de su hijo D. Luis y respuesta del Rey (1613)}

Señor: En Consejo se ha visto un memorial de Don Juan Ferrer Governador de Orihuela que V. Magd. mando remitir los días pasados al Vicecanciller.

En el refiere que ha servido a V. Magd. 48 años continuos, en Oran, en las galeras de España y en los officios de Capitan de Cavallos de la costa del Reyno de Valencia, en el de Lugarteniente General de la Orden de Montesa, y de presente lo continua en el cargo de Governador de Origuela. Que en estos servicios ha gastado la mayor parte de su hazienda, y particularmente en perseguir los bandoleros de aquella Governacion, y assistir a la embarcacion de los Moriscos conforme a las ordenes que se le dieron, sin que se le aya hecho mas merced que de su salario ordinario que es tan moderado como se sabe respecto a los gastos que se le han offrescido y offrescen, y supplica a V. Magd. que attento lo referido, y que desea que sus hijos le imiten sirviendo a V. Magd. como lo hizieron sus pasados le haga V. Mgd. merced de dalle por Adjuncto en el dicho cargo de Governador de Orihuela con futura succession a Don Luys Ferrer su hijo que es el mayor de los quatro que tiene.

Paresce al Consejo que assi por los muchos y mui buenos servicios que representa don Juan (de que aquí se tiene noticia y satisfacion) y por su edad y qualidad, y por la buena relación que ay de las partes y esperanças de don Luis Ferrer su hijo, podría V. Magd, hazelle la merced que supplica de dársele por adjuncto en aquel cargo con futura succession, pues esto también redundara en mayor servicio de V. Magd. y mejor administracion de la justicia. V. Magd. hara lo que mas servido fuere.

Roig Vicecancillerius, Don Monserrat de Guardiola, Regens; D. Philipus Tallada, Regens; Fontanet, Regens; Martinez Boclin, Regens; Perez Manrrique, Regens

El Consejo de Aragon 27 de junio 1613. Sobre lo que supplica don Juan Ferrer Governador de Origuela

El Consejo escuse quanto pudiere de consultarme estas futuras sucesiones por los inconvenientes que traen consigo.

(ACA: CA, Leg. 633, exp. 2/5) 


\section{Documento 8: Terna propuesta por el Virrey, D. Juan Tomas de Rocabertí, Arzobispo de Valencia (1678)}

Señor. Haviendo de proponer sujetos a V. Magd. para el officio de Governador de Orihuela que esta próximo a vacar, por cumplir el tiempo de su Gobierno Don Pedro Boil de Arenos, se me ofrece en primero lugar el Conde de Ana assi por lo authorisado de su persona, por su gran calidad, y por su graduación, como por su talento, juicio, y prudencia a que acompañan muchas otras prendas que le hacen digno de este y maiores empleos en el Real servicio de V. Magd. En segundo, Don Luis Pallas y Vallebrera cuia virtud, canas y experiencias, sobre estar sirviendo el officio de Resetor de esta Baylia General, merecen este y otros mayores premios. El tercero, Don Juan de Cardona. Este es un caballero muy bien visto, de claro juicio, sana intención, muy aplicado, y que llenara el puesto, cumpliendo enteramente con su obligación. V. Magd. hara la elección que mas convenga a su Real servicio y nuestro Señor que la católica y Real persona de V. Magd. como le supplica y la Christiandad ha menester. Valencia y setiembre 27 de 1678. D. Juan T. R Arpo. de Vala.

(ACA: CA, Leg. 797, exp. 33/2)

\section{Documento 9: Terna propuesta por el Virrey, Marqués de Villagarcía (1700)}

Señor. Con carta de veinte ocho del pasado me previene el Sr. Dn. Juan Bauptista Perez Roca de acuerdo del Consejo embie la terna para el govierno de Alicante, que ha vacado por muerte de Dn. Josep de Borxa Lanzol, en cuio cumplimiento propongo a V. Mgd. para el referido Gobierno, sin graduazion a Dn. Vicente Falco y Blanes y a Don Andres de Monserrat Crespi de Balldaura; el primero por la aprovación con que sirve los encargos que se han puesto a su cuidado, prometiendo la experiencia de sus aciertos pueda continuarlos a beneficio del Real servicio en el Gobierno de una ciudad a donde tiene tan acreditada, como es notorio su puntualidad, y proceder, en quanto se le ha encomendado, y al segundo por haver dado muestras muy conformes a sus obligaciones, en mas de treze años que se halla Governador de Castellon de la Plana, en que ha procedido con prudenzia y buena conducta, gran celo y aplicación, desempeñando el crédito de la justicia muy a mi satisfazion y de mi anttezesores en estos cargos, por cuyas razones y las demas que le asisten es muy digno de que V. Mgd. le tenga presente para honrrarle y hacerle merzed en remuneración de sus largos y continuados servicios.

En tercer lugar a Don Sevastian Pertusa, caballero de mucha calidad y buenas prendas que ha servido a V. Mgd. onze años y a sido Capittan de Infanteria vivo y reformado en los exercitos de Cataluña y Milan y en todo lo que se ha ofrecido en este Reyno y se ha puesto en su cuidado pareciéndome muy a propósito para tenerle empleado en cosas que pueda mostrar sus buenos talentos y juicio, aunque no es pretendiente del Gobierno referido.

V. Mgd. se servirá de resolver lo que fuere mas de su Real agrado. Dios guarde la C.R.P. de V. Mgd como la xpsttd. ha menester. Real de Valencia 10 de Agosto de 1700 .

(ACA: CA, Leg. 857, exp. 70/4) 


\section{Documento 10: Consulta del Consejo de Aragón proponiendo terna (1657)}

[En columna al margen] Regentes Conde de Robres, D. Pedro Villacampa, D. Miguel Marta, D. Pasqual de Aragon, D. Vicente Moscoso, D. Josep de Pueyo

Por promoción de Don Luis Ferrer Aragon de Apiano al castillo de San Salvador de Mecina queda otra vez vaco el Gobierno de Orihuela y Alicante en que V. Magd. se sirvió de nombrarle, y dijo el Duque de Montalto Virrey de Valencia en carta para V. Magd. de 28 de octubre del año pasado que siendo tan necesario proveer este puesto, propone para el los mismos sugetos que consulto en primero de febrero de 56, que son

En primer lugar a Don Guillem Carroz

En segundo a Don Juan de Castellvi Villanova

En tercero a Don Antonio Carroz, por las mismas consideraciones que entonces se le ofrecieron, y mandara V. Magd. ver siendo servido por las consultas antecedentes de la provisión deste gobierno que vuelven con esta a su Real mano.

Y añade el Virrey que tiene entendido (y asi se dijo) que en Don Guillem Carroz se hizo reparo por un homicidio que se le imputava, que este caballero es quieto y respectivo a la justicia, que el lance fue casual y sin premeditación alguna y por ser rijoso y no haver prueba del se le dio una pena extraordinaria leve, que en esta desgracia acidental y en sujeto que no acostumbra obrar semejantes desordenes no halla circunstancia alguna que pueda enflaquecer los meritos, siendo asi que por todas las demas calidades es tan a propósito para el puesto y que no es poca la combeniencia del servicio de V. Magd. de que los súbditos vean con aprobación las ternas y el concepto de los Virreyes porque a los que sirven en aquellos puestos no los respetan mas de quanto los ven favorecidos y aprobados. Que juzga por muy importante que V. Magd. se sirva mandar se tome luego resolución en aquel Gobierno porque ha muchos días que se halla sin caveza y no deja de tener grandes inconbenientes que lo substituya Juan Cascant Garcia de Lasa siendo su natural prompto con tanto estremo que pasa a ser especie de furor de donde resultan muchos desaciertos como tiene representado a V. Magd. en otras ocasiones.

En otra carta de 28 de Deziembre vuelve a acordar a V. Magd. la importancia desta provisión con los nuevos motivos que obliga a no diferirla quando se experimentan muntiplizidad de delitos y desordenes en Alicante y Orihuela siendo assi que entre otros a un mismo tiempo le refieren cinco Arcabuzazos en diferentes partes de aquella gobernación, y los tres de ellos con homicidios en que esta empezada a incluir parte de la Nobleza, y puede estarlo toda con grave incombeniente del sosiego publico, y siendo algunos de los interesados parientes de Juan Cascant Theniente de Governador que oy exerce aquel officio se conoce el riesgo que puede padecer la administracion de justicia, que a esto se añade el mal estado de la salud del Assessor, pues no puede moverse sino es con dos muletas con que es mayor la falta de Governador.

Y últimamente en carta de 12 de Henero pasado dize que cada dia crecen los motivos de precisión para el nombramiento de Governador, y que le refieren que es tan grande el abuso de las Armas de fuego en Alicante que aun de dia se traen y públicamente entran en las tiendas para ajustar las valas. Que Pedro Juan Domenech que es oy el subrrogado que asiste al Gobierno de aquella ciudad no tiene bastante autoridad para 
remediar eficazmente estos daños, y suplica el Virrey que se tome breve resolución antes que de todo punto se pierda la quietud de aquel distrito.

Aunque el Consejo por la satisfacion que tiene del proceder de Juan Cascant Garcia de Lasa caballero de la Orden de Santiago y Lugarteniente deste Gobierno le consulto en primer lugar en las dos consultas antecedentes, deja de proponerle ahora, por lo que escribe el Virrey en las dos ultimas cartas referidas de los homicidios que han sucedido en aquella Governacion, en que dize esta incluida la Nobleza con quien tiene tantos vínculos de sangre el dicho Juan Cascant. Y asi propone el Consejo

En primer lugar a Don Diego Sanz de la Llosa caballero de muy buena intención y partes, y que ha servido a V. Magd. en Cathaluña particularmente en las occassiones del socorro de Tarragona y sitio de Tortosa, y que en los estamentos y servicio que ha hecho el Reyno de Valencia ha procedido siempre con mucha satisfacion y se halla con la calidad de hijo y nieto de ministros de V. Magd. que sirvieron en las Plazas de aquella real Audiencia con toda aprobación.

En segundo a Don Juan Pertusa cuyo es el lugar de Vinalesa cavallero de mucha calidad y de conocidas prendas, de buen juicio y zelo del servicio de V. Magd. y que dara muy buena cuenta deste empleo.

En tercero a Don Antonio Carroz capitán de cavallos de una de las compañías de la costa de aquel Reyno, que viene propuesto en el mismo lugar por el Virrey.

El Consejo excluye para esta provission a Don Guillem Carroz que viene en primer lugar por el Virrey, por la muerte que se le imputo. A Don Juan de Castelvi por no tenerle por a propósito para este empleo. Y a Don Phelipe Boyl Varon de Manises (aunque le propuso en las consultas antecedentes en segundo lugar) por haver reconozido después que en las relaciones que hizo el Virrey de los sujetos que procedieron con desatención en las materias del estamento militar fue uno de ellos Don Phelipe Boyl.

El Conde de Albatera se salió del Consejo antes de tratarse de la proposición por ser Pariente de Don Guillem Carroz y de Don Antonio Carroz que vienen propuestos por el Virrey, haviendo propuesto antes. En primer lugar a Juan Cascant Garcia de Lasa por lo que del va referido en las consultas antecedentes.

En segundo a Don Phelipe Boyl Varon de Manises hijo de Don Bernardo Boyl Governador que fue de valencia caballero de buena capacidad y de los de mayor calidad de aquel Reyno.

En tercero a Don Pedro Boyl de Arenos Varon de Boyl y Borriol caballero de mucha calidad y de muy buenas partes, hallase en esta Corte haviendo venido a dar el parabién a V. Magd. en nombre de aquel Reyno del felicisimo nacimiento del Principe nuestro señor.

Don Vicente Pimentel y Moscoso se conforma con el Consejo en los que van propuestos, y excluye a Don Pedro Boyl por ser el sugeto mas opuesto que ay en las materias del servicio de V. Magd. que se tratan en el estamento militar de Valencia como ha representado el Virrey en varias ocasiones. V. Magd. mandara nombrar el que fuere servido. Madrid a 7 de Febrero 1658.

C. de Robres, Don P. Villacpa., Marta Rs. D. Pascal Aragon, R, D. Vicn. Moscoso, Dn. Joseph de Pueyo, R. [firmas]

(ACA: CA, Leg. 664, exp. 31/1) 


\section{Documento 11. Memorial de la ciudad de Orihuela para que se le prorrogue en el cargo por otro trienio al Gobernador D. Diego Sanz de la Llosa (1660)}

Señor: El asierto con que Don Diego Sanz de la Llosa govierna esta ciudad y la mucha atension con que asiste a los negosios comunes sin ambision de utilidades proprias con que conserva en paz y con mucha venerasion a la justisia, los vesinos de ella nos obligan a que con todo rendimiento suppliquemos a V.Magd. sea de su Real servisio confirmarle otro trienio en este gobierno acabado el que oy sirve porque estamos tan bien allados con la prudensia y buen selo deste sujeto y nos prometemos que proseguira su gobierno con la mesma enteresa que asta ahora de que se nos seguiran muchas conveniensias publicas y el Real servicio tendra mucho augmento y lo resebiremos a singular merced de V.Magd. Dios guarde a V.Magd. como todos sus Reynos han menester y estos umildes vasallos deseamos. Orihuela Agosto a 17 de 1660.

Don Antonio Togores jurado, El Dr. Diego Quadra jurado, Thomas Almunia jurado, el Dr. Jayme Martinez jurado (firmas)

(ACA: CA, Leg. 750, exp. 2/1)

\section{Documento 12. D. Francisco Valls y Castellvi al Vicecanciller del Consejo de Aragón excusándose de no poder aceptar el oficio de Gobernador de Orihuela (1673)}

Exmo. Sr: Sr. resibo la de V.Exa. en que se sirve partisiparme la merced que la Reyna nuetsra Sra que dios guarde a sido serbida haserme de el gobierno de Origuela y assiguro a V.Exa. que al paso que quedo con la devida estimasion de tan exsesiva honrra reconosiendome tan sin prendas quedo pesarosso de que a los deseos con que me allo de serbir a Su Magd. no acompañe mi caudal que este es presisso para autorizar tan gran puesto quando el salario es tan corto que no a havido Governador que no quedase destruido y no allandome con medios para poder empeñarme a acetar este empleo me sirve de gran mortificasion aver logrado tan gran dicha que no me he atrevido a pretendella por ser exsesiva assi para mi capasidad como para mi asienda y salud que esta lo gozo arto limitada con ocasión de un acidente de una palpitasion de corazon peligrosa. Estas razones pongo en considerasion a la gran Christiandad de V. Exa. para que por este medio tenga Su Magd. noticia de mi inpusibilidad quedando siempre prompto a obedeser lo que Su Magd. fuere serbida mandarme en mi vida y asienda a que acudire con la fiel puntualidad que en mi cassa siempre a experimentado Su Magd. y espero con el amparo de V.Exa. lograr proporsionada mersed para remedio de mi nesesidad dios lo disponga y guarde la Exma. persona de V.Exa. los muchos años que puede y e menester. Valencia y Mayo 30 de 1673.

Exmo. Sr. Besa los pies de V.Exa su leal Servidor Don Francisco Valls y Castellvi (firma)

Exmo. Sr. Don Melchor de Navarra y Rocafull

(ACA: CA, Leg. 784, exp. 19) 